\title{
Recurrent copy number variations as risk factors for neurodevelopmental disorders: critical overview and analysis of clinical implications
}

\author{
Fátima Torres, ${ }^{1,2}$ Mafalda Barbosa, ${ }^{3,4}$ Patrícia Maciele ${ }^{5,6}$
}

\section{${ }^{1}$ CGC Genetics, Porto, Portuga ${ }^{2}$ Instituto de Ciências Biomédicas Abel Salazar, Universidade do Porto, Porto, Portugal \\ ${ }^{3}$ Department of Genetics and Genomic Sciences, The Mindich Child Health \& Development Institute, The Seaver Autism Center for Research and Treatment, Icahn School of Medicine at Mount Sinai, New York, USA \\ ${ }^{4}$ Instituto Gulbenkian de Ciência, Oeiras, Portugal ${ }^{5}$ Life and Health Sciences Research Institute (ICVS), School of Health Sciences, University of Minho, Braga, Portugal \\ ${ }^{6}$ ICVS/3B's_-PT Government Associate Laboratory, Braga/ Guimarães, Portugal}

\section{Correspondence to} Professor Patrícia Maciel, Life and Health Sciences Research Institute (ICVS), School of Health Sciences, University of Minho, 4710-057 Braga, Portugal; pmaciel@ecsaude. uminho.pt

Received 11 August 2015 Revised 27 September 2015 Accepted 28 September 2015

To cite: Torres $F$, Barbosa M, Maciel P. J Med Genet Published Online First: [please include Day Month Year] doi:10.1136/ jmedgenet-2015-103366

\section{ABSTRACT}

Neurodevelopmental disorders (NDs) encompass a spectrum of neuropsychiatric manifestations.

Chromosomal regions 1q21.1, 3q29, 15q11.2, 15q13.3, $16 p 11.2,16 p 13.1$ and 22q11 harbour rare but recurrent CNVs that have been uncovered as being important risk factors for several of these disorders. These rearrangements may underlie a broad phenotypical spectrum, ranging from normal development, to learning problems, intellectual disability (ID), epilepsy and psychiatric diseases, such as autism spectrum disorders (ASDs) and schizophrenia (SZ). The highly increased risk of developing neurodevelopmental phenotypes associated with some of these CNVs makes them an unavoidable element in the clinical context in paediatrics, neurology and psychiatry. However, and although finding these risk loci has been the goal of neuropsychiatric genetics for many years, the translation of this recent knowledge into clinical practice has not been trivial. In this article, we will: (1) review the state of the art on recurrent CNVs associated with NDs, namely ASD, ID, epilepsy and SZ; (2) discuss the models used to dissect the underlying neurobiology of disease, (3) discuss how this knowledge can be used in clinical practice.

\section{INTRODUCTION}

Neurodevelopmental disorders (NDs) are a large group of clinical entities encompassing a spectrum of neuropsychiatric manifestations caused by disruption of brain development, including autism spectrum disorders (ASD), intellectual disability (ID), communication disorders, attention deficit and hyperactivity disorder (ADHD), specific learning disorders and motor disorders. ${ }^{1}$ Schizophrenia (SZ) has also been proposed to result from neurodevelopmental disturbances, usually manifesting only in the adult stage. ${ }^{2}$ The majority of NDs do not fit the Mendelian disease model where one gene is responsible for a given trait. ${ }^{3}$ Most of them are polygenic or multifactorial and their clustering in families is believed to be influenced by genetic and environmental factors. 4

Two contrasting hypotheses have been advanced to explain the nature of this complexity: the common variant common disease (CVCD) and the rare variant common disease (RVCD) models. ${ }^{5}$ According to the CVCD model, the genetic risk in an individual is attributable to many high frequency variants, each one having a modest effect on risk. In contrast, the RVCD model states that genetic risk in a given individual can be explained by rare mutations that confer significant risk. ${ }^{56}$
Most likely, both types of contribution are important; the narrow-sense heritability in autism is $\sim 52.4 \%$, most being due to common variants. ${ }^{7}$ Rare CNVs-DNA segments larger than $1 \mathrm{~Kb}$ that present a copy number different from that of the reference genome ${ }^{8}$ - contribute to a substantial proportion of the genetic variability in humans ${ }^{9}$ but can also contribute for risk of developing a neurodevelopmental disturbance. Its association with a range of $\mathrm{NDs}^{5}{ }^{10}$ was only possible because advancements in chromosomal microarray (CMA) technology have allowed for CNV analysis in very large case-control cohorts. ${ }^{11}$

A significant proportion of risk for ID, ASD, SZ, epilepsy, bipolar disease (BD) and ADHD can be explained by these rare variants. ${ }^{12-20}$ The estimated risk, or OR, for most common disease-associated single nucleotide polymorphisms will be of-at most - up to 2 (with many between 1.1 and 1.4); in contrast, many-if not most-rare variants have been associated with ORs greater than 2 , in some cases considerably larger. ${ }^{6}$

Most of the experiments to study the impact of CNVs in dosage-sensitive gene expression in normal brain development have used lymphoblastoid cell lines, suggesting a functional impact of CNVs via transcriptome alterations. ${ }^{21-23}$ Two studies on postmortem brain samples have shown that $1 \mathrm{q} 21.1$ and $22 \mathrm{q} 11.2 \mathrm{CNV}$ influence gene expression in the dorsolateral prefrontal cortex; ${ }^{24} 25$ interestingly, a significant proportion of CNVs influencing gene expression in the human prefrontal cortex were located in chromosomal regions implicated in psychiatric disorders, namely those in 1q21.1, 3q29, 15q11.2, 16p11.2, 16p13.1, 17q12 and 22q11.2. ${ }^{25}$

Most recurrent pathogenic $\mathrm{CNVs}$ are large (>400 kb), typically involving dozens of genes, and are individually rare (frequency $<0.1 \%$ ). ${ }^{11}$ Their discovery emphasised the importance of de novo and essentially private mutations in NDs, and indicated that the distinction between milder neuropsychiatric conditions and severe developmental impairment may be a consequence of increased mutational burden affecting multiple genes in the latter case. ${ }^{3}$

Although finding such risk loci has been the goal of neuropsychiatric genetics for many years, the translation of this recent knowledge into clinical practice has not been trivial. In this article, we will: (1) review the state of the art on recurrent $\mathrm{CNVs}$ associated with NDs, namely ASD, ID, epilepsy and SZ; (2) discuss the models used to dissect the underlying mechanism of disease, (3) discuss how this knowledge can be used in clinical practice. 


\section{RECURRENT CNVS ASSOCIATED WITH INCREASED RISK FOR NDS}

The chromosomal regions 1q21.1, 3q29, 15q11.2, 15q13.3, $16 \mathrm{p} 11.2,16 \mathrm{p} 13.1$ and $22 \mathrm{q} 11$ harbour some of the rare recurrent CNVs that have been uncovered as being risk factors for several NDs. Some of these studies are summarised in tables 1-8 and their main aspects discussed below. Other CNVs associated with risk of NDs are listed in table 9.

\section{1q21.1 rearrangements}

The distal 1q21.1 region includes 30 genes and is flanked by segmental duplications that mediate recurrent rearrangements with conserved break points (BP). Recurrent $1.35 \mathrm{Mb}$ deletions/ duplications occur between BP3 and BP4 (figure 1) and confer a risk for a variety of phenotypes (table 1): the deletions are mainly associated with ID and epilepsy, being also enriched in $\mathrm{SZ}$ or schizoaffective disorders, ${ }^{26-31}$ while the duplications are associated with ID and ASD; other findings include seizures, microcephaly/macrocephaly, mild dysmorphisms and congenital abnormalities (CAs). ${ }^{58}$

Of note, there seems to exist a mirror effect on head circumference: deletions cause microcephaly and duplications cause macrocephaly. ${ }^{59}$ These differences might be partially explained by the variable dosage of genes contained in the CNV region. The 1q21.1 HYDIN paralog, which is dosage sensitive and exclusively expressed in the brain, appears to be important in determining head size: an atypical deletion that did not include this gene was observed in a normocephalic patient. ${ }^{59}$ PRKAB2, which encodes the protein kinase, AMP-activated, $\beta-2$ noncatalytic subunit, has effects only when deleted; ${ }^{60}$ this finding is in agreement with previous studies that have demonstrated profound abnormalities in the central nervous system (CNS) in AMP-activated protein kinase (AMPK)-b1-/- knockout mice. ${ }^{61}$

\section{$3 q 29$ rearrangements}

The 3q29 microdeletion (3q29del) is particularly rare $(<1 /$ $1000)$ and was first described in patients with mild-to-moderate ID and slightly dysmorphic facial features. ${ }^{63}$ Since then, other works have associated this deletion with ID, developmental delay (DD), BD, learning disability, $\mathrm{CAs}^{12}{ }^{27}$ and especially with SZ. ${ }^{30-32}$ The reciprocal microduplication is associated with mild-to-moderate ID and CAs (table 2). ${ }^{12} 2763$

3q29del encompasses 21 genes (figure 2), including DLG1, $P A K 2$ and FBX045, that are related to neuronal postsynaptic membrane function and PTEN signalling, and have been proposed as determinant for the psychiatric manifestations of patients harbouring these deletions. ${ }^{64}$ Recently, rare single nucleotide variants as well as small insertions and deletions in FBXO45 were identified in patients with SZ. ${ }^{65}$

\section{5q11.2 (BP1-BP2) deletions}

The 15q11.2 (BP1-BP2) microdeletions (15q11.2del) range from $253 \mathrm{~Kb}$ to $1.5 \mathrm{Mb}$ and have been associated with ID, SZ, DD and ASD, as well as with epilepsy (table 3). ${ }^{33} 3638$ In fact, the combined frequency of this CNV along with $15 \mathrm{q} 13.3 \mathrm{del}$ and $16 \mathrm{p} 13.11 \mathrm{del}$ is approximately $3 \%$ in patients with genetic generalised epilepsy (GGE), ${ }^{66}$ and these CNVs are particularly enriched in patients with ID plus GGE when compared with individuals with GGE or ID alone. ${ }^{1467}$

In spite of its location in the Prader-Willi/Angelman syndrome region, it does not contain the critical genes for these syndromes. This CNV encompasses four non-imprinted genes (figure 3): NIPA1, NIPA2, CYFIP1 and TUBGCP5. ${ }^{36} 38$ Three of them are implicated in CNS development and/or function: NIPA1 and NIPA2 are widely expressed in neuronal tissues and CNS and mediate magnesium $\left(\mathrm{Mg}^{2+}\right)$ transport; ${ }^{68}{ }^{69}$ when mutated, they cause autosomal dominant hereditary spastic paraplegia ${ }^{70}$ and childhood absence epilepsy, ${ }^{71}$ respectively. CYFIP1 is expressed

Table 1 Studies describing association of 1q21.1 deletions and duplications with several NDs

\begin{tabular}{|c|c|c|c|c|c|c|c|c|c|c|}
\hline \multirow[b]{2}{*}{ References } & \multirow[b]{2}{*}{ Phenotype } & \multirow[b]{2}{*}{ del/dup } & \multicolumn{3}{|c|}{ Case group } & \multicolumn{3}{|c|}{ Control group } & \multirow[b]{2}{*}{$\mathrm{p}$ Value } & \multirow[b]{2}{*}{ OR } \\
\hline & & & N & CNVs, $\mathrm{n}$ & Frequency (\%) & $\mathrm{N}$ & CNVs, $\mathbf{n}$ & Frequency (\%) & & \\
\hline 26 & ID/DD/ASD & del & 5218 & 25 & 0.48 & 4737 & 0 & 0 & $1.1 \times 10^{-7}$ & $>22.8$ \\
\hline 27 & ID/DD/ASD/CAs & del & 15749 & 55 & 0.35 & 10118 & 3 & 0.03 & $5.4 \times 10^{-9}$ & 12 \\
\hline 12 & ID/DD/CAs & del & 15767 & 47 & 0.30 & 8329 & 2 & 0.024 & $3.3 \times 10^{-7}$ & 12 \\
\hline 28 & SZ/RP & del & 4718 & 11 & 0.23 & 41199 & 8 & 0.019 & $2.9 \times 10^{-5 *}$ & $\begin{array}{l}12 \\
14.83^{*}\end{array}$ \\
\hline${ }^{29} \dagger$ & SZ & del & 7918 & 17 & 0.21 & $\begin{array}{l}46502 \\
14060 \ddagger\end{array}$ & $\begin{array}{l}11 \\
3 \neq\end{array}$ & $\begin{array}{l}0.024 \\
0.021 \ddagger\end{array}$ & $\begin{array}{l}2.5 \times 10^{-8} \\
9.6 \times 10^{-6} \ddagger\end{array}$ & $\begin{array}{l}9.1 \\
10 \ddagger\end{array}$ \\
\hline 30 & SZ & del & $\begin{array}{c}3945 \\
11392 \S\end{array}$ & $\begin{array}{c}4 \\
20 \S\end{array}$ & $\begin{array}{l}0.10 \\
0.18 \S\end{array}$ & $\begin{array}{c}3611 \\
47321 \S\end{array}$ & $\begin{array}{c}1 \\
10 \S\end{array}$ & $\begin{array}{l}0.028 \\
0.021 \S\end{array}$ & $2.2 \times 10^{-8} \S$ & $\begin{array}{l}3.7 \\
8.3 \S\end{array}$ \\
\hline 31 & SZ & del & $\begin{array}{c}6882 \\
19056 \S\end{array}$ & $\begin{array}{l}12 \\
33 \S\end{array}$ & $0.170 .17 \S$ & $\begin{array}{c}6316 \\
81829 \S\end{array}$ & $\begin{array}{c}1 \\
17 \S\end{array}$ & $0.0160 .021 \S$ & $\begin{array}{l}2.7 \times 10^{-3} \\
4.1 \times 10^{-13} \S\end{array}$ & $\begin{array}{l}11 \\
8.35 \S\end{array}$ \\
\hline 26 & ID/DD/ASD & dup & 5218 & 9 & 0.17 & 4737 & 1 & 0.021 & $2 \times 10^{-2}$ & 8.2 \\
\hline 27 & ID/DD/ASD/CAs & dup & 15749 & 28 & 0.18 & 10118 & 3 & 0.03 & $4 \times 10^{-4}$ & 6 \\
\hline 12 & ID/DD/CAs & dup & 15767 & 25 & 0.16 & 8329 & 6 & 0.07 & $2 \times 10^{-4}$ & 2.2 \\
\hline 30 & SZ & dup & $\begin{array}{r}3945 \\
8563 \ddagger\end{array}$ & $\begin{array}{c}7 \\
11 \ddagger\end{array}$ & $\begin{array}{l}0.18 \\
0.13 \ddagger\end{array}$ & $\begin{array}{c}3611 \\
39809 \ddagger\end{array}$ & $\begin{array}{c}0 \\
14 \ddagger\end{array}$ & $\begin{array}{l}0 \\
0.035 \ddagger\end{array}$ & $2 \times 10^{-3} \ddagger$ & $\begin{array}{l}6.4 \\
3.7 \ddagger\end{array}$ \\
\hline 31 & SZ & dup & $\begin{array}{c}6882 \\
16247 \S\end{array}$ & $\begin{array}{c}8 \\
21^{\mathrm{d}}\end{array}$ & $0.120 .13^{d}$ & $\begin{array}{c}6316 \\
64046^{d}\end{array}$ & $\begin{array}{c}5 \\
24^{d}\end{array}$ & $0.0790 .037^{d}$ & $\begin{array}{l}3.5 \times 10^{-1} \\
9.9 \times 10^{-5 d}\end{array}$ & $\begin{array}{l}1.47 \\
3.45^{d}\end{array}$ \\
\hline
\end{tabular}

p Value: Fisher's exact test, unless specified.

${ }^{*}$ Cochran-Mantel-Haenszel test.

tData obtained from current and previous studies.

$\neq$ Without Icelandic controls.

$\S$ Meta-analysis values, combined data from previous studies and current data set.

ASD, autism spectrum disorder; CA, congenital anomaly (including cardiac, cataract and microcephaly); DD, developmental delay; ID, intellectual disability; ND, neurodevelopmental disorder; SZ/RP, schizophrenia/related psychosis. 
Table 2 Studies describing association of $3 q 29$ deletions and duplications with SZ, schizoaffective disorders and other NDs

\begin{tabular}{|c|c|c|c|c|c|c|c|c|c|c|}
\hline \multirow[b]{2}{*}{ References } & \multirow[b]{2}{*}{ Phenotype } & \multirow[b]{2}{*}{ del/dup } & \multicolumn{3}{|l|}{ Case group } & \multicolumn{3}{|c|}{ Control group } & \multirow[b]{2}{*}{ p Value } & \multirow[b]{2}{*}{ OR } \\
\hline & & & $\mathrm{N}$ & CNVs, $\mathrm{n}$ & Frequency (\%) & $\mathrm{N}$ & CNVs, $\mathbf{n}$ & Frequency (\%) & & \\
\hline 32 & SZ & del & $2457545^{*}$ & $\begin{array}{l}1 \\
6^{*}\end{array}$ & $\begin{array}{l}0.41 \\
0.08^{*}\end{array}$ & $\begin{array}{l}490 \\
39748^{*}\end{array}$ & $\begin{array}{l}0 \\
1 *\end{array}$ & $\begin{array}{l}0 \\
0.0025^{*}\end{array}$ & $9.7 \times 10^{-3 *} \dagger$ & $\begin{array}{l}32^{*} \\
17^{*} \dagger\end{array}$ \\
\hline 30 & SZ & del & $\begin{array}{l}3945 \\
7336^{*}\end{array}$ & $\begin{array}{l}5 \\
7^{*}\end{array}$ & $\begin{array}{l}0.13 \\
0.096 \text { * }\end{array}$ & $\begin{array}{l}3611 \\
14821 \text { * }\end{array}$ & $\begin{array}{l}0 \\
0^{*}\end{array}$ & $\begin{array}{l}0 \\
0 *\end{array}$ & $\begin{array}{l}4 \times 10^{-2} \\
4 \times 10^{-4 *}\end{array}$ & $\begin{array}{l}>4.6 \\
>14^{*}\end{array}$ \\
\hline 31 & SZ & del & $\begin{array}{l}6882 \\
17005^{*}\end{array}$ & $\begin{array}{l}4 \\
14^{*}\end{array}$ & $\begin{array}{l}0.058 \\
0.082 \text { * }\end{array}$ & $\begin{array}{l}6316 \\
69965^{*}\end{array}$ & $\begin{array}{l}0 \\
1^{*}\end{array}$ & $00.0014^{*}$ & $\begin{array}{l}7.4 \times 10^{-2} \\
1.5 \times 10^{-9 *}\end{array}$ & $\begin{array}{l}>3.7 \\
57.65^{\star}\end{array}$ \\
\hline 27 & ID/DD/ASD/CAs & del & 15749 & 9 & 0.057 & 10118 & 0 & 0 & $1.47 \times 10^{-2}$ & $>5.8$ \\
\hline 12 & $\mathrm{ID} / \mathrm{DD} / \mathrm{CAs}$ & del & 15767 & 6 & 0.038 & 8329 & 0 & 0 & $7.85 \times 10^{-2}$ & $>3.2$ \\
\hline 27 & ID/DD/ASD/CAs & dup & 15749 & 8 & 0.050 & 10118 & 1 & 0.0099 & $1 \times 10^{-1}$ & 5.14 \\
\hline 12 & ID/DD/CAs & dup & 15767 & 4 & 0.025 & 8329 & 0 & 0 & $1.83 \times 10^{-1}$ & $>2.1$ \\
\hline
\end{tabular}

$\mathrm{p}$ Value: Fisher's exact test, unless specified.

* Meta-analysis values, combined data from previous studies and current data set.

tCochran-Mantel-Haenszel test.

ASD, autism spectrum disorder; CAs, congenital anomaly (including cardiac, cataract and microcephaly); DD, developmental delay; ID, intellectual disability; ND, neurodevelopmental disorder; SZ: schizophrenia.

in the brain and encodes a protein that interacts with fragile $\mathrm{X}$ mental retardation protein (FMRP), the protein product of the fragile X syndrome gene. ${ }^{72}$ FMRP and CYFIP1 play an important role in the regulation of mRNAs in brain, ${ }^{73}$ and CYFIP1 is critical for the maintenance of dendritic complexity and the stabilisation of mature spines; dysregulation of CYFIP1 expression levels leads to pathological changes in CNS maturation and neuronal connectivity, which may contribute to the development of neuropsychiatric illness. ${ }^{74}$ Finally, TUBGCP5 encodes a widely expressed core component of the gamma tubulin complex, required for microtubule nucleation at the centrosome. ${ }^{75}$

\section{5q13.3 (BP4-BP5) rearrangements}

Sharp and colleagues first described patients with ID, epilepsy and variable facial and digital dysmorphisms due to a $1.5-\mathrm{Mb}$ deletion at $15 \mathrm{q} 13.3$ (15q13.3del), comprising the BP4-BP5 region (figure 3 ). ${ }^{76}$ Patients with reciprocal duplications and a patient with a homozygous deletion and a severe phenotype including epileptic encephalopathy and autistic features were also observed. ${ }^{77} 78$ This deletion is strongly associated with ID $(\mathrm{OR}>29.6)^{27}$ and with SZ and related psychoses, ${ }^{28-31}$ while the reciprocal duplications seem to predispose to ADHD (table 4). ${ }^{20}$ The $15 \mathrm{q} 13.3 \mathrm{del}$ was also recognised as a

Table 3 Studies describing association of BP1-BP2 15q11.2 deletions with several NDs

\begin{tabular}{|c|c|c|c|c|c|c|c|c|c|c|}
\hline \multirow[b]{2}{*}{ References } & \multirow[b]{2}{*}{ Phenotype } & \multirow[b]{2}{*}{ del/dup } & \multicolumn{3}{|c|}{ Case group } & \multicolumn{3}{|c|}{ Control group } & \multirow[b]{2}{*}{ p Value } & \multirow[b]{2}{*}{ OR } \\
\hline & & & $\mathbf{N}$ & CNVs, $\mathrm{n}$ & Frequency (\%) & $\mathrm{N}$ & CNVs, $\mathrm{n}$ & Frequency (\%) & & \\
\hline 28 & SZ/RP & $\begin{array}{l}\text { del } \\
\text { BP1-BP2 }\end{array}$ & 4718 & 26 & 0.55 & 41194 & 79 & 0.19 & $6 \times 10^{-4 *}$ & $\begin{array}{l}2.9 \\
2.73^{*}\end{array}$ \\
\hline${ }^{29} \dagger$ & $\mathrm{SZ}$ & $\begin{array}{l}\text { del } \\
\text { BP1-BP2 }\end{array}$ & 7918 & 49 & 0.62 & $\begin{array}{l}46497 \\
14055 \neq\end{array}$ & $\begin{array}{l}103 \\
45 \ddagger\end{array}$ & $\begin{array}{l}0.22 \\
0.32 \ddagger\end{array}$ & $\begin{array}{l}4.46 \times 10^{-8} \\
1.7 \times 10^{-3} \ddagger\end{array}$ & $\begin{array}{l}2.8 \\
1.94 \ddagger\end{array}$ \\
\hline 31 & SZ & $\begin{array}{l}\text { del } \\
\text { BP1-BP2 }\end{array}$ & $\begin{array}{l}6882 \\
19547 \S\end{array}$ & $\begin{array}{l}44 \\
116 \S\end{array}$ & $\begin{array}{l}0.64 \\
0.59 \S\end{array}$ & $\begin{array}{l}6316 \\
81802 \S\end{array}$ & $\begin{array}{l}26 \\
227 \S\end{array}$ & $\begin{array}{l}0.41 \\
0.28 \S\end{array}$ & $\begin{array}{l}4.6 \times 10^{-2} \\
2.5 \times 10^{-10} \S\end{array}$ & $\begin{array}{l}1.56 \\
2.15 \S\end{array}$ \\
\hline 33 & IGE & $\begin{array}{l}\text { del } \\
\text { BP1-BP2 }\end{array}$ & 1234 & 12 & 0.97 & 3022 & 6 & 0.20 & $4.2 \times 10^{-4}$ & 4.9 \\
\hline 34 & Unexplained ID & $\begin{array}{l}\text { del } \\
\text { BP1-BP2 }\end{array}$ & 1010 & 8 & 0.79 & 2493 & 3 & 0.12 & $3 \times 10^{-3}$ & 6.6 \\
\hline 12 & ID/DD/CAs & $\begin{array}{l}\text { del } \\
\text { BP1-BP2 }\end{array}$ & 15767 & 94 & 0.6 & 8329 & 19 & 0.23 & $2.1 \times 10^{-5}$ & 2.6 \\
\hline 35 & DD/ID/ASD & $\begin{array}{l}\text { del } \\
\text { BP1-BP2 }\end{array}$ & 25113 & 203 & 0.81 & 22246 & 84 & 0.38 & $<1 \times 10^{-4}$ & 2.15 \\
\hline 36 & DD/ASD ADD/ADHD & $\begin{array}{l}\text { del } \\
\text { BP1-BP2 }\end{array}$ & 17000 & 69 & 0.41 & 6329 & 16 & 0.25 & $8.7 \times 10^{-2}$ & 1.6 \\
\hline 37 & ASD & $\begin{array}{l}\text { del } \\
\text { BP1-BP2 }\end{array}$ & 1257 & 4 & 0.32 & 1577 & 4 & 0.25 & $7.4 \times 10^{-1}$ & 1.26 \\
\hline 38 & $\begin{array}{l}\text { ASD } \\
\text { ASD }\end{array}$ & $\begin{array}{l}\text { del } \\
\text { BP1-BP2 }\end{array}$ & $\begin{array}{l}636 \\
4489\end{array}$ & $\begin{array}{l}7 \\
69\end{array}$ & $\begin{array}{l}1.1 \\
1.39\end{array}$ & 1603 & 12 & 0.75 & $\begin{array}{l}4.2 \times 10^{-1} \\
2.5 \times 10^{-1}\end{array}$ & $\begin{array}{l}1.47 \\
1.799\end{array}$ \\
\hline
\end{tabular}

$\mathrm{p}$ Value: Fisher's exact test, unless specified.

${ }^{*}$ Cochran-Mantel-Haenszel test.

tData obtained from current and previous studies.

$\neq$ Without Icelandic controls.

$\S$ Meta-analysis values, combined data from previous studies and current data set.

IASD with normal intelligence.

ADD/ADHD, attention deficit/attention deficit hyperactivity disorder; ASD, autism spectrum disorder; BP, break point; CA, congenital anomaly; DD, developmental delay; ID, intellectual disability; IGE, idiopathic generalised epilepsies; ND, neurodevelopmental disorder; SZ/RP, schizophrenia/related psychosis. 
Table 4 Studies describing association of 15q13.3 Bp4-BP5 deletions and duplications with several NDs

\begin{tabular}{|c|c|c|c|c|c|c|c|c|c|c|}
\hline \multirow[b]{2}{*}{ References } & \multirow[b]{2}{*}{ Phenotype } & \multirow[b]{2}{*}{ del/dup } & \multicolumn{3}{|c|}{ Case group } & \multicolumn{3}{|c|}{ Control group } & \multirow[b]{2}{*}{ p Value } & \multirow[b]{2}{*}{ OR } \\
\hline & & & $\mathrm{N}$ & CNVs, $\mathbf{n}$ & Frequency (\%) & $\mathbf{N}$ & CNVs, $\mathbf{n}$ & Frequency (\%) & & \\
\hline 39 & IGE & $\begin{array}{l}\text { del } \\
\text { BP4-BP5 }\end{array}$ & 1223 & 12 & 0.99 & 3699 & 0 & 0 & $5.3 \times 10^{-8}$ & $>36.6$ \\
\hline 40 & IGE & $\begin{array}{l}\text { del } \\
\text { BP4-BP5 }\end{array}$ & 539 & 7 & 1.3 & 3777 & 0 & 0 & $4.6 \times 10^{-7}$ & $>49.7$ \\
\hline 27 & ID/DD/ASD/CAs & $\begin{array}{l}\text { del } \\
\text { BP4-BP5 }\end{array}$ & 15749 & 46 & 0.29 & 10118 & 0 & 0 & $1.44 \times 10^{-10}$ & $>29.6$ \\
\hline 12 & ID/DD/CAs & $\begin{array}{l}\text { del } \\
\text { BP4-BP5 }\end{array}$ & 15767 & 42 & 0.27 & 8329 & 0 & 0 & $1.8 \times 10^{-8}$ & $>22$ \\
\hline 28 & SZ/RP & $\begin{array}{l}\text { del } \\
\text { BP4-BP5 }\end{array}$ & 4213 & 7 & 0.17 & 39800 & 8 & 0.02 & $5.3 \times 10^{-4 *}$ & $\begin{array}{l}8.3 \\
11.54^{*}\end{array}$ \\
\hline${ }^{29} \dagger$ & $S Z$ & $\begin{array}{l}\text { del } \\
\text { BP4-BP5 }\end{array}$ & 7413 & 15 & 0.20 & $\begin{array}{l}45103 \\
12661 \ddagger\end{array}$ & $\begin{array}{l}8 \\
1 \neq\end{array}$ & $\begin{array}{l}0.018 \\
0.008 \ddagger\end{array}$ & $\begin{array}{l}2.8 \times 10^{-8} \\
3.34 \times 10^{-6} \ddagger\end{array}$ & $\begin{array}{l}11.4 \\
25.7 \ddagger\end{array}$ \\
\hline 30 & SZ & $\begin{array}{l}\text { del } \\
\text { BP4-BP5 }\end{array}$ & $\begin{array}{l}3945 \\
10887 \S\end{array}$ & $\begin{array}{l}7 \\
21 \S\end{array}$ & $\begin{array}{l}0.18 \\
0.19 \S\end{array}$ & $\begin{array}{l}3611 \\
45922 \S\end{array}$ & $\begin{array}{l}1 \\
9 \S\end{array}$ & $\begin{array}{l}0.028 \\
0.018 \S\end{array}$ & $2.0 \times 10^{-9} \S$ & $\begin{array}{l}6.4 \\
9.9 \S\end{array}$ \\
\hline 31 & $S Z$ & $\begin{array}{l}\text { del } \\
\text { BP4-BP5 }\end{array}$ & $\begin{array}{l}6882 \\
18571 \S\end{array}$ & $\begin{array}{l}4 \\
26 \S\end{array}$ & $\begin{array}{l}0.058 \\
0.14 \S\end{array}$ & $\begin{array}{l}6316 \\
80422 \S\end{array}$ & $\begin{array}{l}2 \\
15 \S\end{array}$ & $\begin{array}{l}0.032 \\
0.019 \S\end{array}$ & $\begin{array}{l}3.8 \times 10^{-1} \\
4.0 \times 10^{-10} \S\end{array}$ & $\begin{array}{l}1.84 \\
7.52 \S\end{array}$ \\
\hline 20 & ADHD & $\begin{array}{l}\text { dup } \\
\text { BP4-BP5 }\end{array}$ & 3003 & 37 & 1.25 & 10620 & 64 & 0.61 & $1.78 \times 10^{-4}$ & 2 \\
\hline 27 & ID/DD/ASD/CAs & $\begin{array}{l}\text { dup } \\
\text { BP4-BP5 }\end{array}$ & 15749 & 14 & 0.089 & 10118 & 3 & 0.03 & $8.3 \times 10^{-2}$ & 3 \\
\hline 12 & ID/DD/CAs & $\begin{array}{l}\text { dup } \\
\text { BP4-BP5 }\end{array}$ & 15767 & 20 & 0.12 & 8329 & 3 & 0.036 & $2 \times 10^{-2}$ & 3.5 \\
\hline $\begin{array}{l}\text { p Value: Fish } \\
{ }^{*} \text { Cochran-Ma } \\
\text { †Data obtain } \\
\text { ¥Without Ice } \\
\text { §Meta-analys } \\
\text { ADHD, atten } \\
\text { development }\end{array}$ & $\begin{array}{l}\text { exact test, unless } \\
\text {-Haenszel test. } \\
\text { rom current and p } \\
\text { ic controls. } \\
\text { alues, combined } \\
\text { deficit hyperactivi } \\
\text { elay; ID, intellectu }\end{array}$ & $\begin{array}{l}\text { ified. } \\
\text { us studies. }\end{array}$ & the & dic & 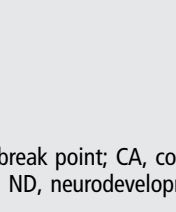 & $1 \mathrm{~d}$ & & $\mathrm{i} / \mathrm{r}$ & $\mathrm{DD}$ & \\
\hline
\end{tabular}

major risk factor $(\mathrm{OR}>50)$ for idiopathic generalised epilepsies (IGE). ${ }^{39}$ In addition to this variable expressivity, incomplete penetrance (ie, healthy individuals presenting these deletions) has been observed, ${ }^{33} 40$ probably due to additional genetic abnormalities, epigenetic factors and/or modifier genes and CNVs. ${ }^{79}$

The critical region of $15 \mathrm{q} 13.3 \mathrm{del}$ harbours at least seven genes (ARHGAP11B, FAN1/MTMR15, MTMR10, TRPM1,

Table 5 Studies describing association of proximal 16p11.2 deletions and duplications with ASD, SZ and other NDs

\begin{tabular}{|c|c|c|c|c|c|c|c|c|c|c|}
\hline \multirow[b]{2}{*}{ References } & \multirow[b]{2}{*}{ Phenotype } & \multirow[b]{2}{*}{ del/dup } & \multicolumn{3}{|c|}{ Case group } & \multicolumn{3}{|c|}{ Control group } & \multirow[b]{2}{*}{$\mathrm{p}$ Value } & \multirow[b]{2}{*}{$\mathrm{OR}$} \\
\hline & & & $\mathrm{N}$ & CNVs, $\mathbf{n}$ & Frequency (\%) & $\mathrm{N}$ & CNVs, $\mathbf{n}$ & Frequency (\%) & & \\
\hline 41 & ASD & $\begin{array}{l}\text { proximal } \\
\text { del }\end{array}$ & 712 & 4 & 0.56 & 837 & 0 & 0 & $4.4 \times 10^{-2}$ & $>4.7$ \\
\hline 42 & ASD & $\begin{array}{l}\text { proximal } \\
\text { del }\end{array}$ & 2195 & 8 & 0.37 & 2519 & 4 & 0.16 & $2.5 \times 10^{-1}$ & 2.3 \\
\hline 27 & ID/DD/ASD/CAs & $\begin{array}{l}\text { proximal } \\
\text { del }\end{array}$ & 15749 & 67 & 0.43 & 10118 & 5 & 0.049 & $6.3 \times 10^{-10}$ & 8.4 \\
\hline 12 & ID/DD/CAs & $\begin{array}{l}\text { proximal } \\
\text { del }\end{array}$ & 15767 & 64 & 0.41 & 8329 & 3 & 0.037 & $3.4 \times 10^{-9}$ & 11.3 \\
\hline 30 & SZ & $\begin{array}{l}\text { proximal } \\
\text { del }\end{array}$ & $\begin{array}{l}3945 \\
9890^{*}\end{array}$ & $\begin{array}{l}1 \\
4^{*}\end{array}$ & $\begin{array}{l}0.025 \\
0.04^{*}\end{array}$ & $\begin{array}{l}3611 \\
29597^{*}\end{array}$ & $\begin{array}{l}3 \\
11^{*}\end{array}$ & $\begin{array}{l}0.08 \\
0.037^{*}\end{array}$ & $5.4 \times 10^{-1 *}$ & $\begin{array}{l}0.91 \\
1.09^{*}\end{array}$ \\
\hline 30 & SZ & $\begin{array}{l}\text { proximal } \\
\text { dup }\end{array}$ & $\begin{array}{l}3945 \\
9890^{*}\end{array}$ & $\begin{array}{l}13 \\
31^{*}\end{array}$ & $\begin{array}{l}0.33 \\
0.31^{*}\end{array}$ & $\begin{array}{l}3611 \\
29597^{*}\end{array}$ & $\begin{array}{l}1 \\
8^{*}\end{array}$ & $\begin{array}{l}0.028 \\
0.027^{*}\end{array}$ & $1.5 \times 10^{-12 *}$ & $\begin{array}{l}11.9 \\
11.6^{*}\end{array}$ \\
\hline 31 & SZ & $\begin{array}{l}\text { proximal } \\
\text { dup }\end{array}$ & $\begin{array}{l}6882 \\
16772^{*}\end{array}$ & $\begin{array}{l}27 \\
58^{*}\end{array}$ & $\begin{array}{l}0.39 \\
0.35^{*}\end{array}$ & $\begin{array}{l}6316 \\
63068^{*}\end{array}$ & $\begin{array}{l}0 \\
19^{*}\end{array}$ & $00.03^{*}$ & $\begin{array}{l}2.3 \times 10^{-8} \\
2.9 \times 10^{-24 *}\end{array}$ & $\begin{array}{l}>24.9 \\
11.5^{*}\end{array}$ \\
\hline 42 & ASD & $\begin{array}{l}\text { proximal } \\
\text { dup }\end{array}$ & 2195 & 9 & 0.41 & 2519 & 4 & 0.16 & $1.6 \times 10^{-1}$ & 2.6 \\
\hline 27 & ID/DD/ASD/CAs & $\begin{array}{l}\text { proximal } \\
\text { dup }\end{array}$ & 15749 & 39 & 0.25 & 10118 & 4 & 0.098 & $2.5 \times 10^{-5}$ & 6.28 \\
\hline 12 & ID/DD/CAs & $\begin{array}{l}\text { proximal } \\
\text { dup }\end{array}$ & 15767 & 28 & 0,18 & 8329 & 2 & 0.024 & $4 \times 10^{-4}$ & 7.4 \\
\hline
\end{tabular}

$\mathrm{p}$ Value: Fisher's exact test, unless specified.

*Meta-analysis values, combined data from previous studies and current data set.

ASD, autism spectrum disorder; CAs, congenital anomaly (including cardiac, cataract and microcephaly); DD, developmental delay; ID, intellectual disability; ND, neurodevelopmental disorder; SZ, schizophrenia. 
Table 6 Studies describing association of distal 16p11.2 deletions and duplications with ASD, SZ and other NDs

\begin{tabular}{|c|c|c|c|c|c|c|c|c|c|c|}
\hline \multirow[b]{2}{*}{ References } & \multirow[b]{2}{*}{ Phenotype } & \multirow[b]{2}{*}{ del/dup } & \multicolumn{3}{|c|}{ Case group } & \multicolumn{3}{|c|}{ Control group } & \multirow[b]{2}{*}{$\mathrm{p}$ Value } & \multirow[b]{2}{*}{ OR } \\
\hline & & & $\mathrm{N}$ & CNVs, $\mathbf{n}$ & Frequency (\%) & $\mathrm{N}$ & CNVs, $\mathbf{n}$ & Frequency (\%) & & \\
\hline 43 & SZ & $\begin{array}{l}\text { distal } \\
\text { del }\end{array}$ & 13850 & 13 & 0.094 & 19954 & 3 & 0.015 & $1 \times 10^{-3}$ & 6.25 \\
\hline 31 & SZ & $\begin{array}{l}\text { distal } \\
\text { del }\end{array}$ & $\begin{array}{l}6882 \\
20732 *\end{array}$ & $\begin{array}{l}0 \\
13^{*}\end{array}$ & $\begin{array}{l}0 \\
0.063^{*}\end{array}$ & $\begin{array}{l}6316 \\
27045^{*}\end{array}$ & $\begin{array}{l}2 \\
5^{*}\end{array}$ & $\begin{array}{l}0.032 \\
0.018^{*}\end{array}$ & $\frac{1}{1.7 \times 10^{-2 *}}$ & - \\
\hline 12 & ID/DD/CAs & $\begin{array}{l}\text { distal } \\
\text { del }\end{array}$ & 15767 & 15 & 0.095 & 8329 & 1 & 0.024 & $1.1 \times 10^{-2}$ & 7.9 \\
\hline 44 & DD & $\begin{array}{l}\text { distal } \\
\text { del }\end{array}$ & 23084 & 31 & 0.13 & 7700 & 1 & 0.013 & $3 \times 10^{-3}$ & 10.4 \\
\hline 12 & ID/DD/CAs & $\begin{array}{l}\text { distal } \\
\text { dup }\end{array}$ & 15767 & 14 & 0.089 & 8329 & 2 & 0.012 & $4.9 \times 10^{-2}$ & 3.7 \\
\hline 44 & DD & $\begin{array}{l}\text { distal } \\
\text { dup }\end{array}$ & 23084 & 17 & 0.07 & 7700 & 3 & 0.04 & $4 \times 10^{-1}$ & 1.9 \\
\hline
\end{tabular}

p Value: Fisher's exact test, unless specified.

*Meta-analysis values, combined data from previous studies and current data set.

ASD, autism spectrum disorder; CA, congenital anomaly (including cardiac, cataract and microcephaly); DD, developmental delay; ID, intellectual disability; ND, Neurodevelopmental disorder; SZ, schizophrenia.

KLF13, OTUD7A and CHRNA7), but CHRNA7 soon emerged as a prime candidate gene responsible for some of the clinical findings associated with these CNVs, such as seizures, because of the identification of individuals with deletions containing only this gene. ${ }^{80}$ CHRNA7 encodes the cholinergic receptor alpha 7 (neuronal), which belongs to the nicotinic acetylcholine receptor (nAChRs) superfamily of ligand-gated ion channels that mediate signal transmission at synapses. It plays roles in central and peripheral nervous system development, cognitive performance and inflammation; ${ }^{81}$ it is highly expressed in the reticular thalamus, indicating a role in modulating thalamocortical pathways, which are central to the generation of primary generalised seizures seen in IGE. Indirect evidence for its role in epileptogenesis comes from the fact that mutations in other nAChR family members cause autosomal dominant nocturnal frontal lobe epilepsy. ${ }^{39}{ }^{40}$ Nevertheless, no patients with point mutations in CHRNA7 gene were described until now: ${ }^{62} 82$ only some non-coding variants associated with reduced gene expression have been found in one patient with $\mathrm{ASD}^{83}$ as well as in patients with $\mathrm{SZ} .{ }^{81}$ The $\mathrm{a} 7 \mathrm{nAChR}$ is also a relevant pharmacological target, as agonists of nAChRs are currently being considered in the treatment of NDs. ${ }^{84-86}$ In a maternal immune activation (MIA) mouse model, a murine model of environmental risk factors for autism and SZ, it was shown that this receptor modulates the inflammatory response after MIA, affecting the fetal brain development and offspring behaviour. The a7nAChR suppresses inflammatory response in the fetal brain by inhibiting interleukin (IL) 6 production and, consequentially, the loss of Chrna7 in the offspring increases their vulnerability to MIA-induced autistic and SZ-like symptoms. Maternal choline supplementation triggers an anti-inflammatory response in the fetal brain and thus decreases the MIA-induced IL-6 elevation during embryonic stage and the autistic and SZ-like behaviours in the adults. ${ }^{87}$

Whole-exome sequencing (WES) data combined with a statistical method designed to identify the responsible gene(s) within

Table 7 Studies describing association of 16 p13.11 deletions and duplications with several NDs

\begin{tabular}{|c|c|c|c|c|c|c|c|c|c|c|}
\hline \multirow[b]{2}{*}{ References } & \multirow[b]{2}{*}{ Phenotype } & \multirow[b]{2}{*}{ del/dup } & \multicolumn{3}{|c|}{ Case group } & \multicolumn{3}{|c|}{ Control group } & \multirow[b]{2}{*}{$\mathrm{p}$ Value } & \multirow[b]{2}{*}{ OR } \\
\hline & & & $\mathrm{N}$ & CNVs, $\mathrm{n}$ & Frequency (\%) & $\mathrm{N}$ & CNVs, $\mathrm{n}$ & Frequency (\%) & & \\
\hline 45 & ID/CAs & del & 1027 & 5 & 0.49 & $2014^{*}$ & 0 & 0 & $4.8 \times 10^{-3}$ & $>9.85$ \\
\hline 27 & ID/DD/ASD/CAs & del & 15749 & 22 & 0.14 & 10118 & 3 & 0.03 & $6.3 \times 10^{-3}$ & 4.7 \\
\hline 12 & ID/DD/CAs & del & 15767 & 18 & 0.11 & 8329 & 3 & 0.036 & $3.6 \times 10^{-2}$ & 3.2 \\
\hline 46 & $\mathrm{SZ}$ & del & 4345 & 5 & 0.12 & 35079 & 15 & 0.04 & $>5 \times 10^{-2}$ & 2.7 \\
\hline 33 & IGE & del & 1234 & 6 & 0.49 & 3022 & 2 & 0.066 & $9 \times 10^{-3}$ & 7.4 \\
\hline 47 & ES & del & 3812 & 23 & 0.60 & 1299 & 0 & 0 & NA & $>7.88$ \\
\hline 45 & ID/CAs & dup & 1027 & 7 & 0.68 & $2014^{*}$ & 5 & 0.25 & $1.27 \times 10^{-1}$ & 2.8 \\
\hline 27 & ID/DD/ASD/CAs & dup & 15749 & 45 & 0.29 & 10118 & 20 & 0.2 & $2 \times 10^{-1}$ & 1.4 \\
\hline 12 & ID/DD/CAs & dup & 15767 & 24 & 0.15 & 8329 & 10 & 0.12 & $3.3 \times 10^{-1}$ & 1.3 \\
\hline 48 & ADHD & dup & $\begin{array}{l}366 \\
825 t\end{array}$ & $\begin{array}{l}6 \\
4 \dagger\end{array}$ & $\begin{array}{l}1.67 \\
0.49 \dagger\end{array}$ & $\begin{array}{l}1047 \\
35243 \dagger\end{array}$ & $\begin{array}{l}1 \\
36 t\end{array}$ & $\begin{array}{l}0.096 \\
0.1 \dagger\end{array}$ & $\begin{array}{r}8 \times 10^{-4} \\
3.1 \times 10^{-2} \dagger\end{array}$ & $\begin{array}{l}17.4 \\
4.76 \dagger\end{array}$ \\
\hline 46 & SZ & dup & 4345 & 13 & 0.30 & 35079 & 32 & 0.09 & $7 \times 10^{-3}$ & 3.3 \\
\hline 31 & $S Z$ & dup & $\begin{array}{l}6882 \\
12029 \ddagger\end{array}$ & $\begin{array}{l}24 \\
37 \ddagger\end{array}$ & $\begin{array}{l}0.35 \\
0.31 \neq\end{array}$ & $\begin{array}{l}6316 \\
69289 \ddagger\end{array}$ & $\begin{array}{l}12 \\
93 \ddagger\end{array}$ & $0.190 .13 \ddagger$ & $\begin{array}{r}5.6 \times 10^{-2} \\
5.7 \times 10^{-5} \ddagger\end{array}$ & $\begin{array}{r}1.84 \\
2.30 \ddagger\end{array}$ \\
\hline
\end{tabular}

p Value: Fisher's exact test, unless specified.

*Used their own controls with already described data.

tReplication Icelandic group.

¥Meta-analysis values, combined data from previous studies and current data set.

ADHD, attention deficit hyperactivity disorder; ASD, autism spectrum disorder; CA, congenital anomaly (including cardiac, cataract and microcephaly); DD, developmental delay; ES,

epilepsy syndrome; ID, intellectual disability; IGE, idiopathic generalised epilepsy; NA, not available; ND, neurodevelopmental disorder; SZ, schizophrenia. 
Table 8 Studies describing association of $22 q 11.2$ deletions and duplications with SZ and other NDs

\begin{tabular}{|c|c|c|c|c|c|c|c|c|c|c|}
\hline \multirow[b]{2}{*}{ References } & \multirow[b]{2}{*}{ Phenotype } & \multirow[b]{2}{*}{ del/dup } & \multicolumn{3}{|c|}{ Case group } & \multicolumn{3}{|c|}{ Control group } & \multirow[b]{2}{*}{$p$ Value } & \multirow[b]{2}{*}{ OR } \\
\hline & & & $\mathrm{N}$ & CNVs, $\mathbf{n}$ & Frequency (\%) & $\mathbf{N}$ & CNVs, $\mathbf{n}$ & Frequency (\%) & & \\
\hline 32 & SZ & del & $\begin{array}{l}245 \\
6107^{*}\end{array}$ & $\begin{array}{l}2 \\
29 *\end{array}$ & $\begin{array}{l}0.82 \\
0.48^{*}\end{array}$ & $\begin{array}{l}490 \\
6502^{*}\end{array}$ & $\begin{array}{l}0 \\
0^{*}\end{array}$ & $\begin{array}{l}0 \\
0 *\end{array}$ & $4.7 \times 10^{-10 *} \dagger$ & $>31 *$ \\
\hline 30 & SZ & del & $\begin{array}{l}3945 \\
11400 \text { * }\end{array}$ & $\begin{array}{l}21 \\
35^{*}\end{array}$ & $\begin{array}{l}0.54 \\
0.31^{*}\end{array}$ & $\begin{array}{l}3611 \\
45361 \text { * }\end{array}$ & $\begin{array}{l}0 \\
0 *\end{array}$ & $\begin{array}{l}0 \\
0 *\end{array}$ & $<1.0 \times 10^{-16 *}$ & $\begin{array}{l}>19 \\
>139 *\end{array}$ \\
\hline 31 & $S Z$ & del & $\begin{array}{l}6882 \\
19084^{*}\end{array}$ & $\begin{array}{l}20 \\
56^{*}\end{array}$ & $\begin{array}{l}0.29 \\
0.29 *\end{array}$ & $\begin{array}{l}6316 \\
77055^{*}\end{array}$ & $\begin{array}{l}0 \\
0 *\end{array}$ & $\begin{array}{l}0 \\
0 *\end{array}$ & $\begin{array}{l}2.2 \times 10^{-6} \\
4.4 \times 10^{-40 *}\end{array}$ & $\begin{array}{l}>18 \\
>226^{*}\end{array}$ \\
\hline 27 & ID/DD/ASD/CAs & del & 15749 & 93 & 0.59 & 10118 & 0 & 0 & $9.1 \times 10^{-21}$ & $>60$ \\
\hline 12 & ID/DD/CAs & del & 15767 & 96 & 0.61 & 8329 & 0 & 0 & $<1 \times 10^{-4}$ & $>51$ \\
\hline 42 & ASD & dup & 2195 & 9 & 0.41 & 2519 & 0 & 0 & $1 \times 10^{-3}$ & $>10$ \\
\hline 27 & ID/DD/ASD/CAs & dup & 15749 & 32 & 0.20 & 10118 & 5 & 0.049 & $1.1 \times 10^{-3}$ & 4.1 \\
\hline 12 & ID/DD/CAs & dup & 15767 & 50 & 0.32 & 8329 & 5 & 0.06 & $1.3 \times 10^{-5}$ & 5.3 \\
\hline
\end{tabular}

regions affected by de novo CNVs, allowed the discovery of a new gene containing rare risk variants for SZ and ASD located in $15 \mathrm{q} 13.3$. Fanconi-associated nuclease 1 (FAN1) is relatively widely expressed in brain and encodes a DNA repair enzyme. ${ }^{88}$ Individuals carrying a homozygous microdeletion spanning FAN1 show severe neurodevelopmental abnormalities, including microcephaly. ${ }^{89}$ It is likely that deleterious FAN1 mutations increase risk for SZ and ASD by interfering with aspects of early neuronal development, namely proliferation. ${ }^{88}$

\section{$16 p 11.2$ rearrangements}

The 593-Kb proximal deletions and duplications at $16 \mathrm{p} 11.2$ (figure 4), although observed in individuals with normal phenotypes, ${ }^{90}$ have been associated with a broad range of NDs (table 5). A detailed phenotypical analysis of the 16p11.2 CNV has shown the existence of partially mirroring phenotypes: the deletion is associated with ASD, ID, behavioural disorders, CAs, diabetes-independent obesity and macrocephaly, while the reciprocal duplication is associated with autism and SZ, anorexia and microcephaly. ${ }^{41}$ 91-95 Jacquemont and colleagues have thus speculated that head circumference and neuronal circuitry abnormalities could be linked to cognitive function and energy balance impairments in patients with $16 \mathrm{p} 11.2$ rearrangements, and so the abnormal food intake could be a direct result of a particular ND. ${ }^{95}$ Conceptually, this would make us add obesity to the list of CNV-associated NDs, an intriguing shift to the field, but one that fits the increasing knowledge on the biology of food intake and metabolism regulation by the CNS. ${ }^{96}$

KCTD13 is one of the 29 annotated genes within this CNV, among some transcription factors (eg, MAZ, TBX6), chromatin

Table 9 Selected studies describing association of other risk loci with NDs

\begin{tabular}{|c|c|c|c|c|}
\hline Gene & Associated CNV & Location & Phenotype & References \\
\hline NRXN1 & del & $2 \mathrm{p} 16.3$ & ASD/SZ & $3149-52$ \\
\hline CNTN4 & del/dup & $3 p 26$ & ASD & 5354 \\
\hline UBE3A; PARK2; RFWD2; FBXO40; NLGN1; ASTN2 & $\begin{array}{l}\text { del/dup within or } \\
\text { surrounding genes }\end{array}$ & $\begin{array}{l}15 q 11.2 / 6 q 25.2-q 27 \\
1 q 25.1-q 25.2 / 3 q 13.33 \\
3 q 26.31 / 9 q 33.1\end{array}$ & ASD & 42 \\
\hline SHANK2; SYNGAP1; DDX53-PTCHD1 DLGAP2 & $\begin{array}{l}\text { Del } \\
\text { dup }\end{array}$ & $\begin{array}{l}11 q 13.3 / 6 p 21.32 / X p 22.1 \\
8 p 23.3\end{array}$ & ASD & 16 \\
\hline SHANK1; SHANK2; SHANK3 & $\begin{array}{l}\text { del/dup, truncating } \\
\text { mutations }\end{array}$ & $19 q 13.3 / 11 q 13.3 / 22 q 13.3$ & $\begin{array}{l}\text { ASD/ID/SZI } \\
\text { ADHD/BD }\end{array}$ & 55 \\
\hline WBS region (38 genes) & dup & $7 q 11.23$ & ASD/SZ & 18315657 \\
\hline USP7; C16orf72; CDH13 & dup & $\begin{array}{l}16 \mathrm{p} 13.2 \\
16 q 23.3\end{array}$ & ASD & 18 \\
\hline COMMD1; CACNA2D4; CTNNA3; CTNND2 & del & $\begin{array}{l}2 p 15 / 12 p 13.33 \\
10 q 22.2 / 5 p 15.2\end{array}$ & ASD & 17 \\
\hline JAKMIP1; NLGN4Y; OXTR; ABAT & del & $\begin{array}{l}4 p 16.1 / Y q 11.221 \\
3 p 25 / 16 p 13.2\end{array}$ & ASD & 50 \\
\hline DRG1; GJA1; EPHA5; SPOCK3 & $\begin{array}{l}\text { dup } \\
\text { del }\end{array}$ & $\begin{array}{l}10 q 11.23 / 6 q 22.31 / 4 q 13.1 \\
4 q 32.3\end{array}$ & ASD & 10 \\
\hline $\begin{array}{l}\text { FMO; DNM; SATB2; PEX13 to AHSA2; JAGN1 to TATDN2; CHMP2B to } \\
\text { POU1F1; GAP43; FGF12; BMP3; MEF2C; SFTPD to GLUD1, including } \\
\text { NRG3; SCNN1A to PIANP }\end{array}$ & del/dup & $\begin{array}{l}1 q 24 / 2 q 33.1 / 2 p 15-16.1 / 3 p 25.3 / 3 p 11.2 / \\
3 q 13 / 3 q 28-29 / 4 q 21 / 5 q 14 / 9 p 13 / 10 q 11 / \\
10 q 23.1 / 12 p 13\end{array}$ & $\mathrm{DD}$ & 52 \\
\hline
\end{tabular}

ADHD, attention deficit and hyperactivity disorder; ASD, autism spectrum disorder; BD, bipolar disease; DD, developmental delay; ID, intellectual disability; ND, neurodevelopmental disorder; SZ, schizophrenia. 

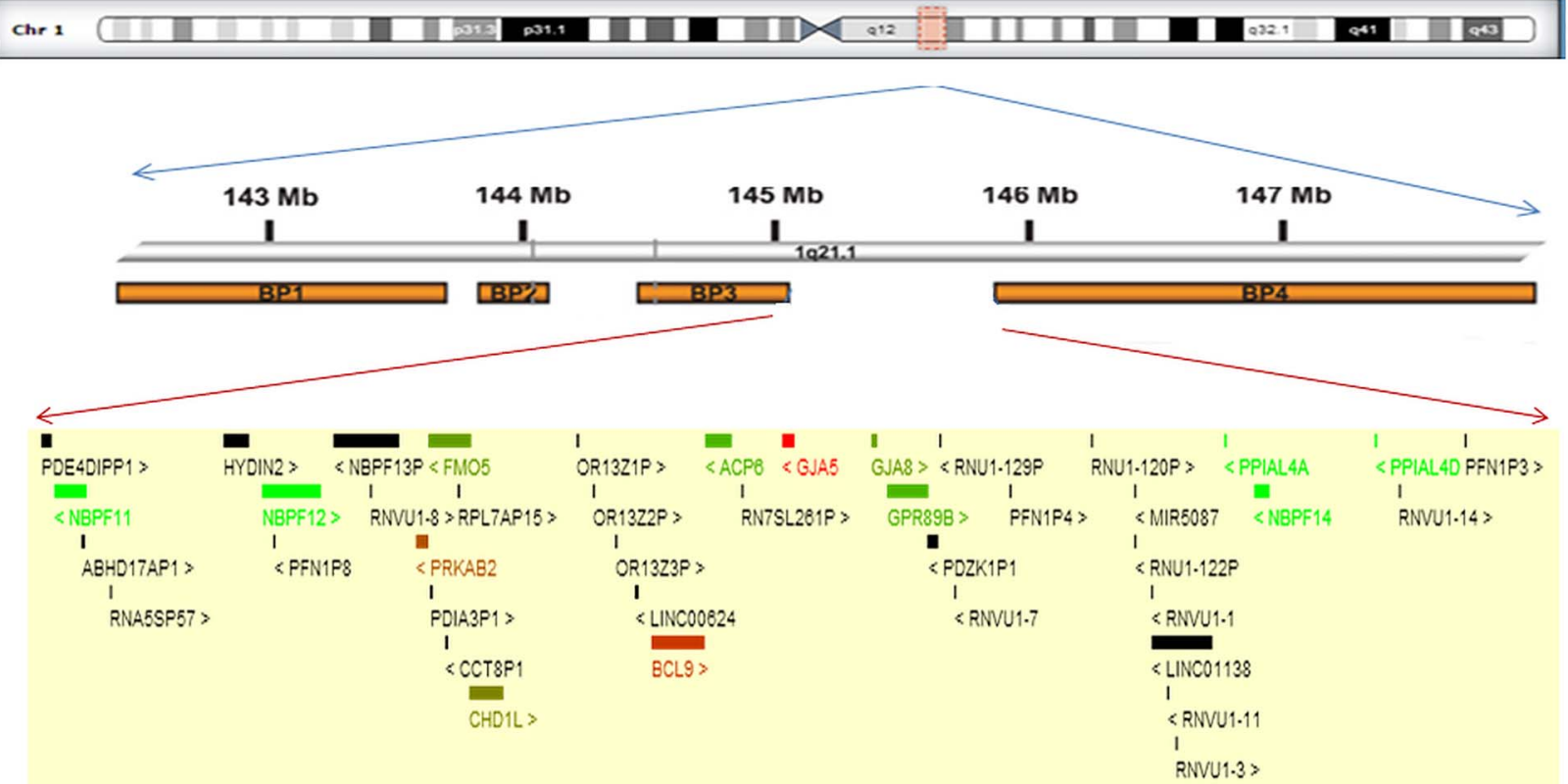

Figure 1 Distal 1q21.1 CNVs: recurrent 1.35 Mb deletions/duplications between break points BP3 and BP4 (chr1: 146.5-147.9 Mb). Protein-coding genes are marked in colour, the remaining are marked in black. Within protein-coding, genes have been scored according to their predicted probability of exhibiting haploinsufficiency: in red are the genes more likely to exhibit haploinsufficiency, in green the genes less likely to exhibit haploinsufficiency (adapted from Firth and colleagues ${ }^{161}$ ).

modifiers (eg, HIRIP3, INO80E) and other genes with a wide array of cellular functions. The use of zebra fish and mouse models revealed that KCTD13 is a major driver of the head size phenotypes associated with the 16p11.2-CNV through the regulation of early neurogenesis. Moreover, KCTD13 dosage changes were related with autism in a family with a reduced 16 p11.2 deletion (encompassing only five genes, one of them being KCTD13), and a patient with a narrow diagnosis of autism and a complex $16 \mathrm{p} 11.2$ rearrangement involving de novo structural alteration of KCTD13. ${ }^{97}$ RNA sequencing of

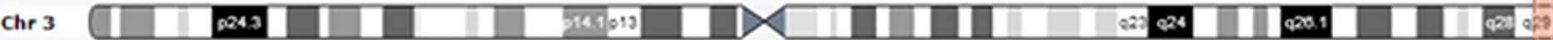

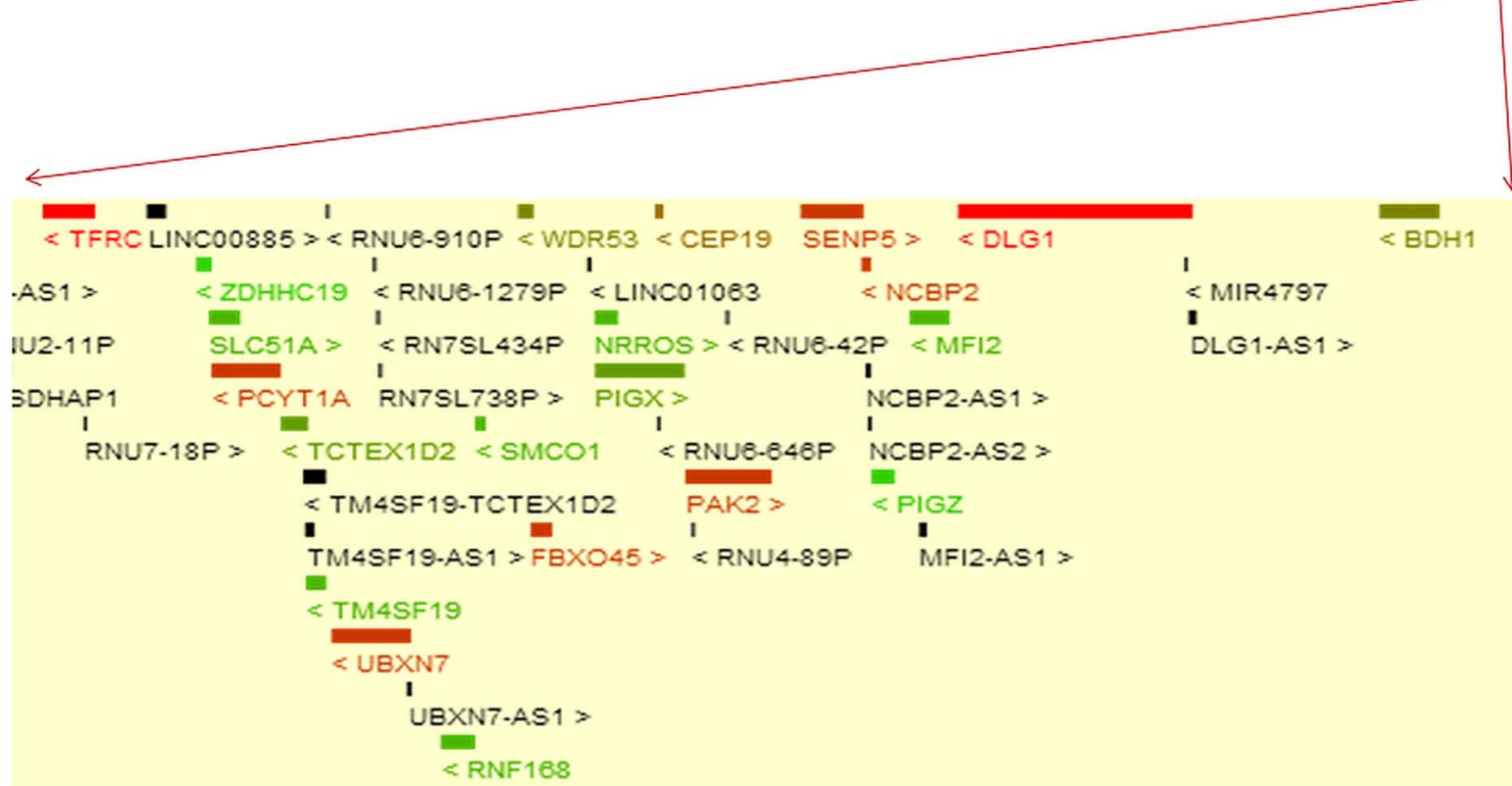

Figure $23 q 29$ CNVs: recurrent 1.6 Mb deletions/duplications (chr3: 195.7-197.3 Mb). Protein-coding genes are marked in colour, the remaining are marked in black. Within protein-coding, genes have been scored according to their predicted probability of exhibiting haploinsufficiency: in red are the genes more likely to exhibit haploinsufficiency, in green the genes less likely to exhibit haploinsufficiency (adapted from Firth and colleagues $^{161}$ ). 


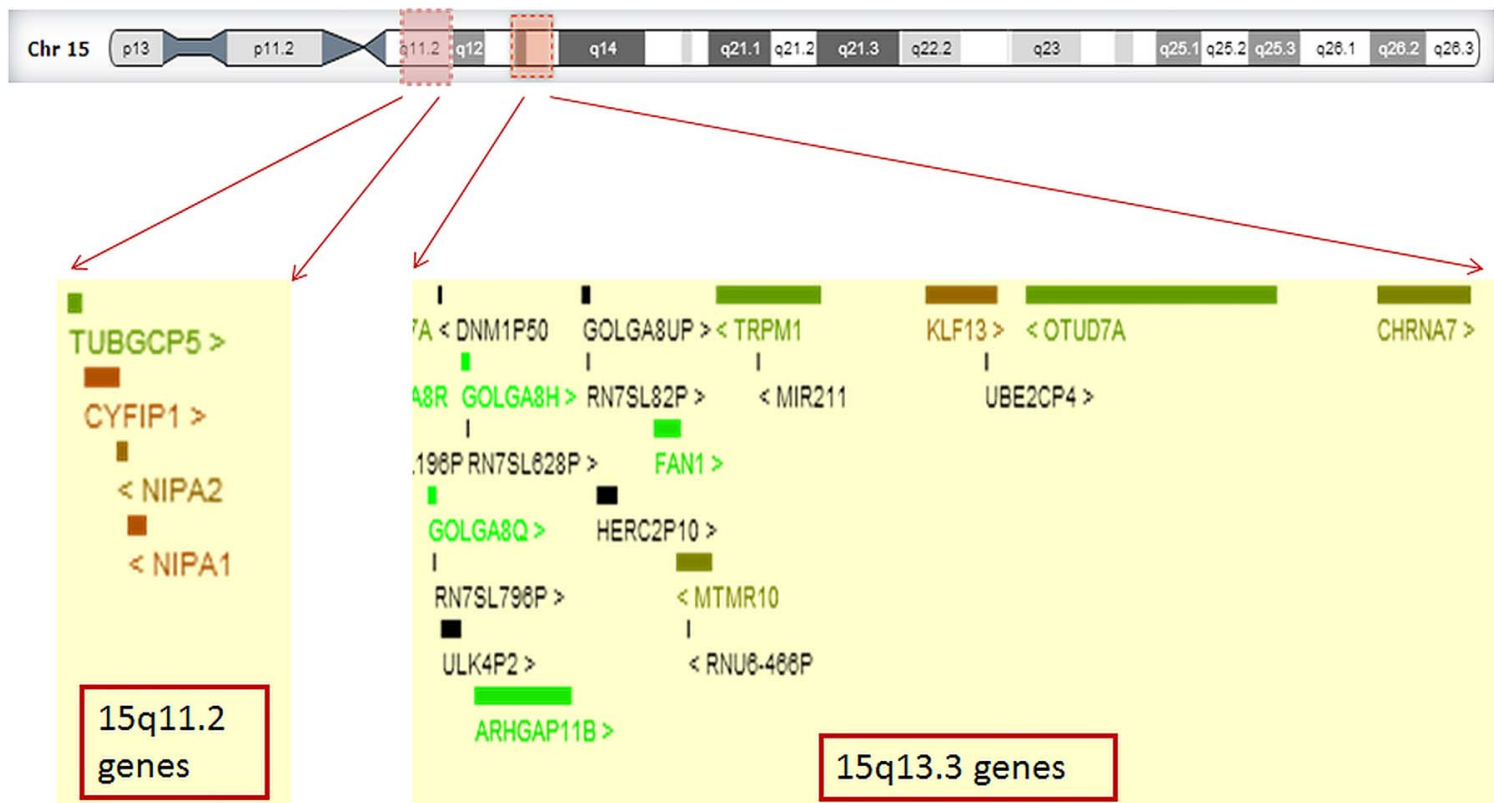

Figure 3 Chromosome 15 CNVs: recurrent 15q11.2 (break points (BP)1-BP2) deletions, ranging from $253 \mathrm{~Kb}$ to $1.5 \mathrm{Mb}$ and encompassing the four non-imprinted genes NIPA1, NIPA2, CYFIP1, TUBGCP5 and 15q13.3 (BP4-BP5) deletions/duplications (chr15: 30.91-32.44 Mb). Protein-coding genes are marked in colour, the remaining are marked in black. Within protein-coding, genes have been scored according to their predicted probability of exhibiting haploinsufficiency: in red are the genes more likely to exhibit haploinsufficiency, in green the genes less likely to exhibit haploinsufficiency (adapted from Firth and colleagues ${ }^{161}$ ).

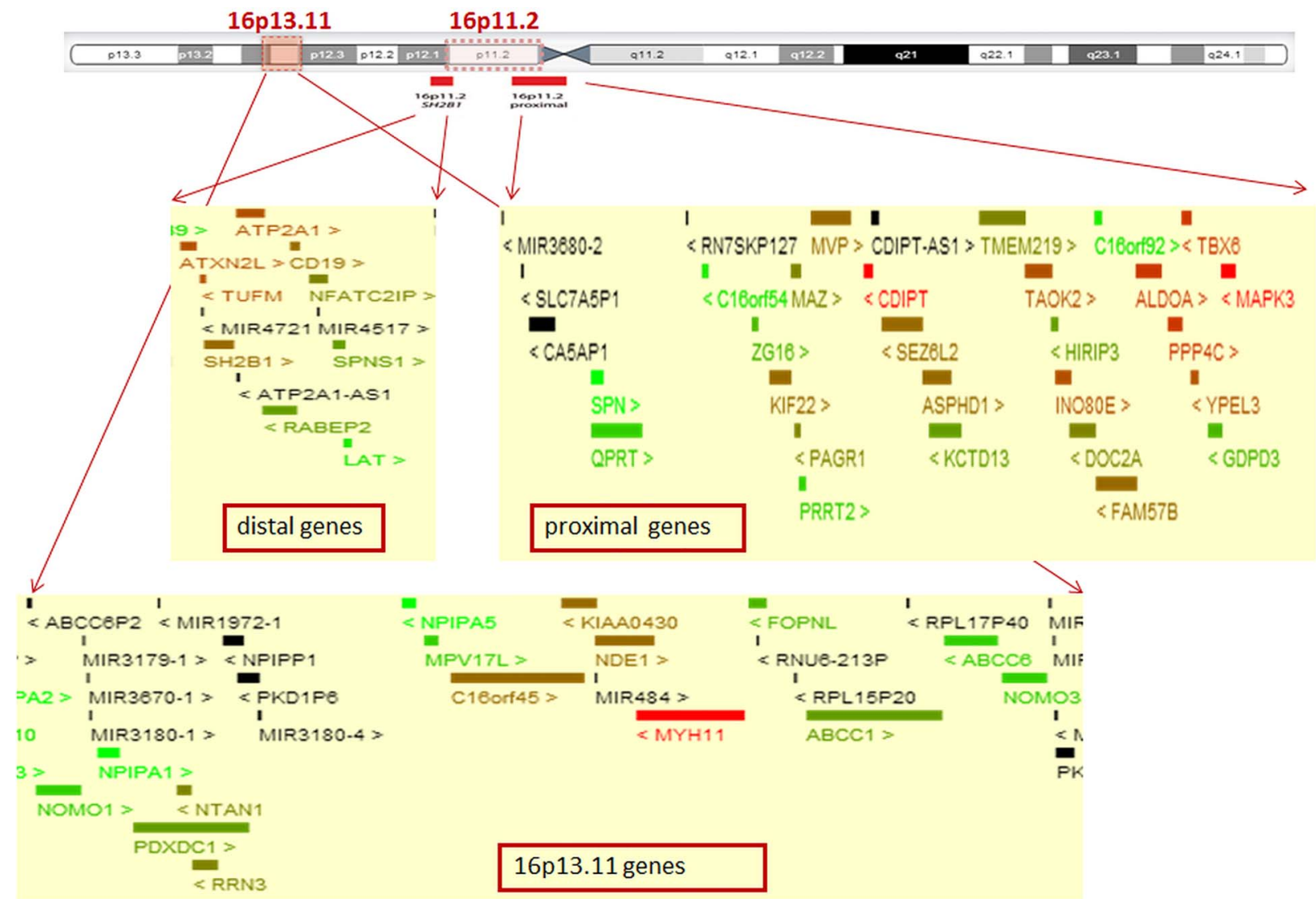

Figure 4 Chromosome 16 CNVs: recurrent 16p11.2 deletions/duplications, proximal (chr16: 29.60-30.19 Mb) and distal (chr16: 28.73-28.95 Mb); recurrent 16p13.11 deletions/duplications (chr16: 14.98-16.48 Mb). Protein-coding genes are marked in colour, the remaining are marked in black. Within protein-coding, genes have been scored according to their predicted probability of exhibiting haploinsufficiency: in red are the genes more likely to exhibit haploinsufficiency, in green the genes less likely to exhibit haploinsufficiency (adapted from Firth and colleagues ${ }^{161}$ ). 
cerebral cortex of mouse models with duplication/deletion and cell lines derived from multiplex ASD families with the CNV showed that expression of all genes in the CNV region correlated well with their DNA copy number. Effects of $16 \mathrm{p} 11.2$ rearrangements on gene expression outside the $\mathrm{CNV}$ region were also observed, including apparent positional effects in cis and in trans and dysregulation of genes located in other chromosomal regions. In conclusion, alteration of $16 \mathrm{p} 11.2$ genes seems to disrupt expression networks that involve other genes and pathways known to contribute to ASD. ${ }^{98}$

The 220-kb 16p11.2 distal deletion (28.73-28.95 Mb) was first described in association with severe early onset obesity alone. ${ }^{99}$ Soon after, it was also described in patients with DD, ID and other variable phenotypical features in addition to obesity ${ }^{12} 44$ and, more recently, in association with SZ (table 6). ${ }^{31} 43$

The minimal deleted region contains nine genes, several of which are implicated in neurological diseases (TUFM, ATP2A1), immunity and glucose homoeostasis. The most likely obesity candidate gene was postulated to be $S H 2 B 1$, involved in leptin and insulin signalling, ${ }^{100}$ and implicated in the regulation of body weight and glucose homoeostasis in mice. ${ }^{101}$

\section{$16 p 13.11$ rearrangements}

Common features of the patients with the $1.5 \mathrm{Mb}$ deletions at 16p13.11 (16p13.11del) include ID, microcephaly and epilepsy, while patients carrying the reciprocal duplication have pronounced behavioural problems in addition to ID and/or CAs. $^{45} 102$

A threefold excess of duplications and deletions has been observed in SZ cases (table 7), ${ }^{3146}$ and both rearrangements have been implicated in ADHD. ${ }^{48} 103$

The $16 \mathrm{p} 13.11 \mathrm{del}$ is significantly associated with GGE 3367104 and appears to be the most prevalent single genetic risk factor for overall seizure susceptibility $(0.6 \%$ of patients with epilepsy). $^{47}$

The $16 \mathrm{p} 13.11$ consensus region spans seven genes (MPV17L, C16orf45, KIAA0430, NDE1, MYH11, C16orf63, ABCC1) (figure 4). ${ }^{48} 103$ Among them, the nuclear distribution gene $\mathrm{E}$ homologue 1 (NDE1) is of particular interest, because the nudE neurodevelopment protein 1 is essential for mitosis and neurodevelopment, and interacts with the disrupted in SZ 1 protein, ${ }^{105}$ implicated in SZ and in other major psychiatric disorders. ${ }^{106-108}$ NDE1 deficiency impairs neurogenesis, by causing profound neuronal proliferation defects and a deficiency in cortical lamination, as observed in Nde1-null mice and in patients with NDE1 homozygous mutations, who present extreme microcephaly with lissencephaly. ${ }^{106} 107$ Severe microcephaly, including fetal brain disruption, can also be caused by the combination of a $16 \mathrm{p} 13.11 \mathrm{del}$ and a mutation on the nondeleted NDE1 homologue. ${ }^{108}$ As the $16 \mathrm{p} 13.11$ region includes other genes expressed during brain development, such as ABCC1, NOMO1, NTAN1, PDXDC1, it has been suggested that sequencing these candidate genes for second-hit mutations in patients with $16 \mathrm{p} 13.11 \mathrm{del}$ and severe neurodevelopmental phenotypes could give new insights into these disorders. ${ }^{108}$

\section{2q11.2 rearrangements}

DiGeorge syndrome, velocardiofacial syndrome or $22 \mathrm{q} 11.2$ deletion syndrome (22q11DS) results from 1.5-3 Mb heterozygous microdeletions on $22 \mathrm{q} 11.2$ locus; these deletions (22q11.2del) represent one of the most common disease-causing CNVs. The associated phenotype is variable but frequently includes cleft palate, hypocalcaemia, cardiac defects, immune dysfunction and neuropsychiatric illness. ${ }^{109-111}$ About $85 \%$ of patients with 22q11DS have the $3 \mathrm{Mb}$ deletion ( $\sim 60$ genes), while the remainder have the smaller $1.5 \mathrm{Mb}$ deletion $(28$

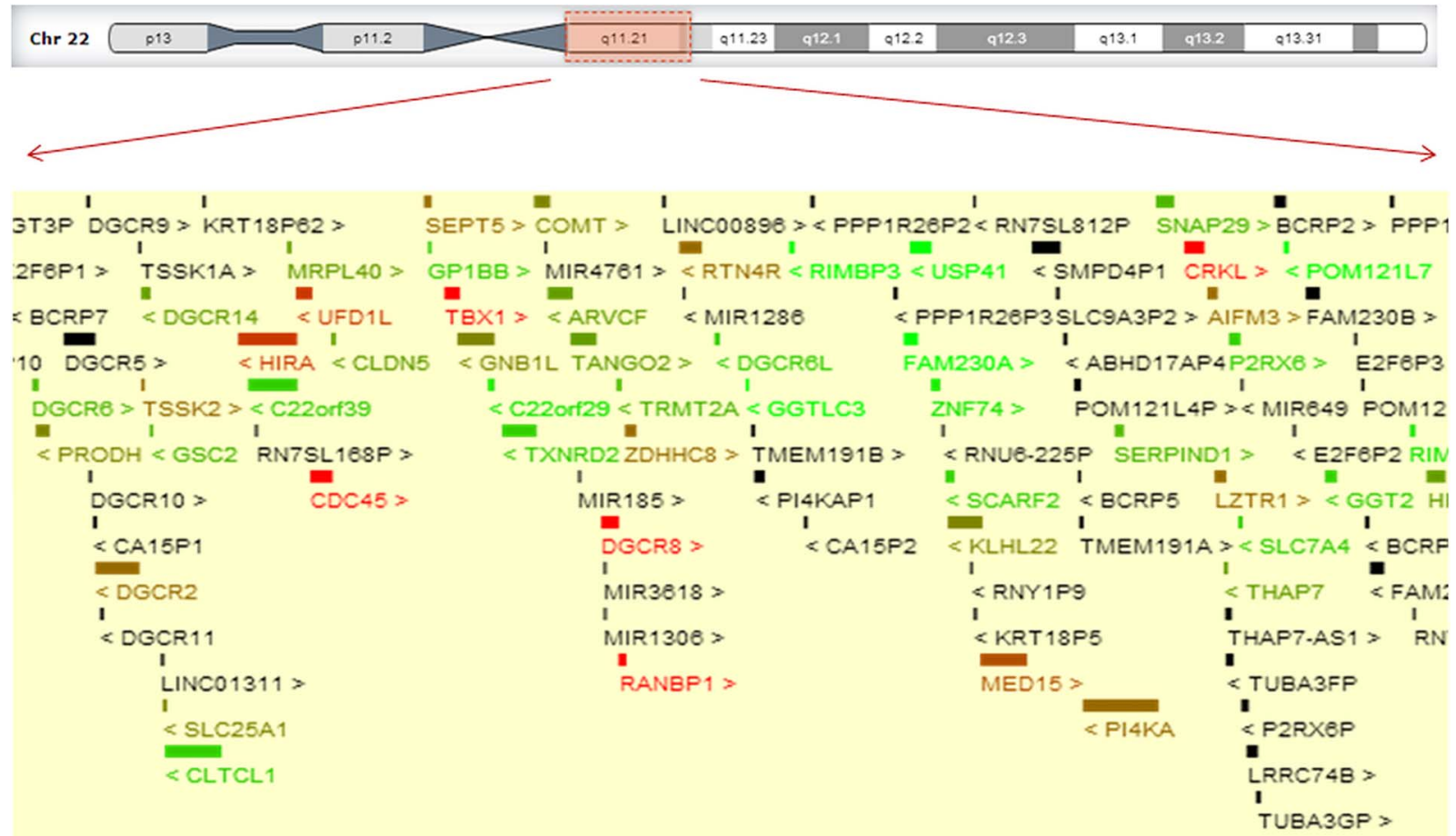

Figure 5 Recurrent 22q11.2 CNVs (chr22: 19.00-21.45 Mb). Protein-coding genes are marked in colour, the remaining are marked in black. Within protein-coding, genes have been scored according to their predicted probability of exhibiting haploinsufficiency: in red are the genes more likely to exhibit haploinsufficiency, in green the genes less likely to exhibit haploinsufficiency (adapted from Firth and colleagues ${ }^{161}$ ). 
genes), or atypical deletions, containing a small number of genes (figure 5). ${ }^{111}$

Patients with 22q11DS have variable psychiatric and cognitive presentations: children have a high prevalence of ASD, ADHD, anxiety disorders and psychotic features ${ }^{112}$ while up to $30 \%$ of adolescents and adults develop SZ or affective psychosis. ${ }^{113} 114$ The 22q11.2del was the first CNV implicated in $\mathrm{SZ}^{115}$ and is now considered one of the greatest known risk factors for psychotic illness, accounting for up to $1-2 \%$ of sporadic cases of SZ (table 8). ${ }^{30} 31111114$

The reciprocal $3 \mathrm{Mb}$ duplication is usually associated with milder and more variable phenotypes: DD, speech delay and cognitive deficits have been reported in $50-80 \%$ of the patients, but asymptomatic carriers were also observed (table 7). ${ }^{42} 109$ 116-119

Data from genetic association studies in human patients and control subjects, indicate that a substantial number of genes are likely to contribute to 22q11DS key phenotypes. ${ }^{120}$

The TBX1 gene, although responsible for some major aspects of the phenotype of 22q11.2DS (abnormal facies, cardiac defects, thymic hypoplasia, velopharyngeal insufficiency of the cleft palate and parathyroid dysfunction with hypocalcaemia), does not seem to be responsible for the cognitive/neuropsychiatric features commonly seen in patients with 22q11DS. ${ }^{121}$

Two other genes within this CNV are COMT and PRODH. The COMT gene encodes a postsynaptic enzyme that modulates dopaminergic clearance ${ }^{122}$ and, given the association between dopamine deficits and several psychiatric disorders such as SZ and $\mathrm{ADHD},{ }^{123}$ has been widely investigated. The functional polymorphism Val158Met (rs4680) affects enzyme activity and dopamine availability in brain areas where this neurotransmitter is released, such as the prefrontal cortex. The high-activity $\mathrm{COMT}^{158}$ Val allele has, therefore, been suggested as a small but reliable risk factor for SZ, at least for people of European ancestry. 124

The PRODH gene encodes the enzyme that converts proline to glutamate in mitochondria, dysfunction of which has been linked to the development of psychiatric illness, including SZ. ${ }^{125}$ There is also evidence for epistatic interaction between COMT and PRODH: Prodh-deficient mice show Comt upregulation in prefrontal cortex, which likely represent a homoeostatic response to enhanced dopaminergic signalling resulting from Prodh deficiency, ${ }^{126}$ and elevated plasma proline levels. ${ }^{127}$ If COMT upregulation is indeed one of the mechanisms used to control cortical dopaminergic hypersensitivity, then most patients with 22q11DS who are haploinsufficient for both genes, particularly those who have the low-activity COMT ${ }^{158}$ Met allele, may be at a particular disadvantage because they are unable to compensate efficiently, through COMT, for the cortical dopaminergic hyperactivity induced by PRODH deficiency. ${ }^{114} 126127$

Based on human and mouse model studies of $22 \mathrm{q} 11.2$ rare CNVs, Hiroi proposed that alterations of a distinct set of multiple, non-contiguous genes encoded in this chromosomal region, together with environmental factors and modulatory impacts of the genetic background, could variably shift the probabilities of phenotypes along a predetermined developmental trajectory. ${ }^{128}$

\section{IMPACT OF CNVS}

The predictive value of genetic variants depends, in part, on their penetrance, defined as the probability of an individual with a certain genotype to present a phenotype at all, whereas the concept of variable expressivity pertains to the variability in the spectrum of symptoms/phenotype.

Vassos and colleagues estimated the penetrance of CNVs associated with SZ, at $15 \mathrm{q} 13.3,1 \mathrm{q} 21.1,15 \mathrm{q} 11.2,17 \mathrm{p} 12,2 \mathrm{p} 16.3$, $16 \mathrm{p} 13.1$ and $16 \mathrm{p} 11.2$ and concluded that the highest penetrance was observed for $15 \mathrm{q} 13.3 \mathrm{del}(6-9 \%)$ and the lowest for $15 \mathrm{q} 11.2 \mathrm{del}(2 \%){ }^{129}$ Calculation of the frequencies of $70 \mathrm{impli}-$ cated CNVs in patients, controls and the general population led to the conclusion that, except for 16p11.2dup, 3q29del, 16p13.11dup and the smaller 15q13.3 (CHRNA7) duplications, the penetrance of CNVs is higher for the development of a disorder from the group of DD/ASD/CAs than for SZ. This observation has also strengthened the evidence of a genetic overlap, at least for some CNVS, among DD, ASD and SZ; some CNVs are so highly pathogenic and penetrant that they cause earlier-onset disorders, such as DD/ASD/CAs, precluding the diagnosis of SZ. ${ }^{130}$

\section{Studying the functional impact of CNVs and the neurobiology of NDs}

The identification of this unexpectedly abundant type of genetic variation and the increasingly clear role of CNVs in NDs has led to the need to develop appropriate models for the study of disease pathogenesis, aiming at the development of therapeutic strategies for these diseases.

Despite the difficulty of modelling all aspects of human psychiatric and neurodevelopmental phenotypes in animals (eg, hallucinations and delusions characteristic of SZ, hard to characterise in other species), animal models may contribute to the elucidation of brain anatomy, functional connectivity, cognitive and behavioural features, and also molecular mechanisms that reflect aspects of human phenotypes. ${ }^{131}$ Among the most used are mouse models, which can be engineered in several ways: some express multiple genes within the human chromosomal region that is being studied; others have the syntenic region deleted or duplicated; finally, there are individual gene knockout or overexpression models which allow us to dissect the contribution of a particular gene to a given phenotype. $^{131} 132$ Other models, like zebra fish or Caenorhabditis elegans, are also used particularly to assess the function of particular genes. ${ }^{133} 134$ More recently, the possibility of using human induced pluripotent stem cells (hiPSCs) has opened a wide range of experiment possibilities, including in drug screening. ${ }^{135}$

\section{Animal models}

Animal models of CNV-related neurodevelopmental impairment are not very numerous but some interesting examples exist that illustrate the possibilities in this field.

Haploinsufficieny of Cyfip1, believed to be one of the key aspects of the $15 \mathrm{q} 11.2$ (BP1-BP2) deletions, produces fragile-X-like phenotypes in mice, which is consistent with a role for the interaction of Cyfip1 and Fmrp in regulating activity-dependent translation in neurons. ${ }^{136}$

A $15 \mathrm{q} 13.3$ microdeletion mouse model (Df(h15q13)/_), generated by hemizygous deletion of the orthologous region, displays key phenotypes including SZ, epilepsy and aggression, all associated with the human syndrome. ${ }^{137}$

Mice with deletion (as well as reciprocal duplication) of the chromosomal region corresponding to the human $16 \mathrm{p} 11.2$ locus, have provided functional evidence that $16 \mathrm{p} 11.2-\mathrm{CNV}$ cause brain and behavioural anomalies. Notably, the macrocephaly (with deletion) and microcephaly (with duplication) observed in human subjects were replicated in mice. Regarding behaviour, 16p11.2del mice showed hyperactivity, difficulty 
adapting to change, sleeping abnormalities, and repetitive or restricted behaviours, while $16 \mathrm{p} 11.2 \mathrm{dup}$ animals were hypoactive. ${ }^{138}$ Half of the $16 \mathrm{p} 11.2 \mathrm{del}$ mice died postnatally, suggesting a potential link between $16 \mathrm{p} 11.2-\mathrm{CNVs}$ and infant mortality, that remains to be explored in humans; those that survived to adulthood were healthy and fertile, but exhibited behaviour changes characteristic of rodents with lateral hypothalamic and nigrostriatal lesions. ${ }^{138}$

Consistently with human postmortem studies showing that neuronal migration abnormalities in the cerebral cortex are a feature of $22 \mathrm{qDS},{ }^{139}$ diminished dosage of $22 \mathrm{q} 11$ genes disrupts neurogenesis and cortical development in mice. ${ }^{140}$ The 22q11.2del disrupts an established molecular mechanismCxcr4-mediated signalling-that regulates cortical interneuron migration and placement. ${ }^{141}$ Deficits of various degrees across hippocampus and alterations in synaptic plasticity and structural connectivity within the prefrontal cortex, thought to be contributors to the 22q11.2-related cognitive and psychiatric impairments, were shown to occur in other 22q11.2del mouse models. ${ }^{142}{ }^{143}$ Altered brain microRNAs and abnormalities in the formation of neuronal dendrites and spines, including those in corticocerebellar, corticostriatal and corticolimbic circuits were also observed in these models. ${ }^{144} 145$ Future studies with these mouse models should allow an increased understanding of pathogenic processes underlying NDs as well as the design and testing of suitable therapeutic strategies for these disorders.

\section{Human induced pluripotent stem cells}

hiPSCs are adult pluripotent stem cells generated from somatic cells that can be derived from adult humans, and represent a potentially limitless source of human cells to study disease: hiPSCs also make possible the study of human neurons, a previously inaccessible cell type, carrying the genetic information from patients with a specific mutation or a neuropsychiatric disease. ${ }^{146}$

Patient-derived cells (eg, dermal fibroblasts from a skin biopsy or peripheral blood mononuclear cells) can be reprogrammed into iPSCs by forced expression of four pluripotency-associated transcription factors: OCT4, SOX2, KLF4 and c-MYC. These cells are similar to human embryonic stem cells in morphology, proliferation, surface antigens, gene expression, epigenetic status of pluripotent cell-specific genes and telomerase activity. ${ }^{147}$

Although there are no publications to date describing the CNVs described here, hiPSCs have been used to model NDs that include autistic features: neurons differentiated from hiPSCs of affected individuals or from genetically modified hiPSCs exhibited disease-related phenotypes, such as fewer synapses, smaller soma size, deficits in calcium signalling and in spontaneous excitatory synaptic communication, when compared with unaffected control neurons. ${ }^{148}$ hiPSC-derived neurons in patients with SZ showed an aberrant migration, increased oxidative stress, ${ }^{149}$ significantly reduced neuronal connectivity, reduced neurite outgrowth, reduced dendritic levels of PSD95 and altered gene expression profiles; interestingly, key cellular and molecular elements of the SZ phenotype were ameliorated following treatment of SZ hiPSC neurons with the antipsychotic loxapine. ${ }^{150}$

The limitations of hiPSC-based approaches for studying psychiatric disease are mainly neuron-to-neuron variability, hiPSC-to-hiPSC variability and patient-to-patient variability and, therefore, hiPSC-based studies will not replace MRI, postmortem and genetic studies of patients with psychiatric disorders. ${ }^{151}$ Nevertheless, the development of these models opens new avenues for the deeper understanding of pathogenic mechanisms and-importantly-for the development of new therapeutic strategies for these disorders, by means of large-scale screening of chemical libraries with disease-specific hiPSCs. ${ }^{135}$

\section{TRANSLATION OF THE RECENT KNOWLEDGE TO THE CLINICAL CONTEXT-GENETIC COUNSELLING}

Until recently, counselling of a patient/family with history of neuropsychiatric disease too often meant discussion of empirical risks since in the majority of cases the aetiology was not known. A good deal of the counselling session would be dedicated to clearly transmitting the value and limitations of these empirical risks and what this would translate into in the patient's and his/ her relatives' life. In this context, unburdening the patient, parents and extended family from stigma and guilt was-and still is-paramount.

The technological advances in molecular genetics in the last decade-namely CMA and WES-have, however, revolutionised the field of medical genetics regarding diagnostic yield.

As a matter of fact, the 15-20\% diagnostic yield of CMA led multiple medical entities (such as the American College of Medical Genetics, American Academy of Neurology and the American Academy of Pediatrics) to recommend microarray as a first-tier clinical diagnostic test for individuals with ASD, ID/DD or multiple CAs. ${ }^{152}$ This contributed to: (A) a better understanding of the entire spectrum of fully penetrant genes and regions that cause syndromic NDs, the current understanding being that the spectrum fades into non-syndromic mild ID and ASD; (B) detection of CNVs that are significantly enriched in cases but also present in controls. In fact, the highly increased risk of developing neurodevelopmental phenotypes associated with some of these CNVs makes them an unavoidable element in the clinical context in paediatrics, neurology and psychiatry and should be addressed by a multidisciplinary clinical team, ideally including a geneticist.

Both scenarios are challenging in terms of counselling. In the case of a child with a significant disability (in the context of syndromic or non-syndromic disease) due to a de novo CNV with complete penetrance, genetic counselling has straightforward medical benefits such as a tailored follow-up for the child, accurate genetic counselling for the family and the possibility of prenatal diagnosis. Much greater challenge is faced when counselling for a recurrent $\mathrm{CNV}$ with known incomplete penetrance and/or variable expressivity, or when there is a degree of uncertainty on whether the CNV indeed poses risk for health: in this case, the translation of this recent knowledge into clinical practice has not been trivial. Even though it may be tempting to postpone its use in the clinical context-until more solid data or guidelines are developed-the complexity of these findings should be embraced since some of these CNVs present ORs above 5 that have been replicated in independent studies. Interestingly, risk factors for cancer development or cardiovascular disease frequently have lower multivariate-adjusted ORs and yet they are heavily used in a patient's clinical management. This is because many of these risk factors are preventable (eg, obesity) or help us set a lower threshold for screening or intervention. But the same applies for ND, where early intervention (eg, stimulation and behavioural therapy) and identification of other factors that could contribute to developmental difficulties or arrest (eg, vision and hearing screening) should be considered.

\section{Incomplete penetrance and variable expressivity}

It is known that deletions and duplications of the same locus can present with identical and mirror features. Also, in general, 
the penetrance of deletions is higher than that of duplications. For example, $16 \mathrm{p} 11.2 \mathrm{del}$ are more penetrant and more frequently de novo events than duplications. ${ }^{153}$

In addition to incomplete penetrance, many CNVs also present variable expressivity. For example, the 15q13.3del may be detected in individuals who are ascertained with different NDs such as ID, SZ and BD. This may be viewed as interfamilial variability. However, this can also translate into intrafamilial variability in a scenario where, for example, a child with ASD has an apparently healthy mother and maternal relatives with $\mathrm{SZ}$ and BD. The recognition of the incomplete penetrance and the variable expressivity is needed in order to assemble the relevant information for counselling.

Penetrance and variable expressivity might be influenced by other genetic, epigenetic and environmental factors. Different risk elements might contribute to the preferential development of one neurophenotype over another, as well as determine severity. Different models to explain variable expressivity have been suggested: additive (two co-occurring CNVs affecting independent functional modules/pathways) and epistatic (two CNVs affecting the same functional module/pathway). ${ }^{154}$ The study of more than 20000 cases and around 14500 controls offered evidence for the additive model in the case of $16 \mathrm{p} 12.1 \mathrm{del}^{155}$

\section{Carriers, controls and general population}

Neuropsychiatric profiling of patients with 22q11.2del has shown that these patients present a wide IQ range, from normal to moderate ID (ie, -3 SD below the mean. ${ }^{156} \mathrm{~A}$ similar study design was used to evaluate patients with $16 \mathrm{p} 11.2 \mathrm{del}$, which showed that individuals with the deletion had an average IQ 1 SD below the population mean). However, when compared with relatives without the deletion, individuals with the 16 p11.2 deletion had a 1.8 standard deviation loss. ${ }^{157}$

Two conclusions can be inferred: (1) the very same damaging CNV might impact differently in different individuals, depending on their genetic background; (2) one may be able to predict the phenotypical severity of an individual with a deleterious $\mathrm{CNV}$ by using parents as proxies. This knowledge could be useful in postnatal diagnosis, for tailored follow-up and early intervention, and in prenatal care. ${ }^{158}$

Complementary, detailed study of carriers of neuropsychiatric CNVs revealed that they show cognitive abilities and brain structure changes situated between those of controls (ie, without a neuropsychiatric $\mathrm{CNV}$ ) and patients with NDs, even though they often did not fulfil criteria for ASD, ID or SZ. ${ }^{159}$ One could speculate that what is sometimes perceived as lack of penetrance is actually variable expressivity, which could be detectable provided more granular phenotyping had been performed.

\section{Prenatal diagnosis}

Counselling in a prenatal diagnosis setting is a particularly delicate task. This is true in the case of a de novo fully penetrant pathogenic CNV, but even more so for CNVs with incomplete penetrance and variable expressivity or for variants of uncertain significance. The latter is a rare event (about $1 \%)^{160}$ but a source of great anxiety and request of multiple/serial complementary exams in the hope of shedding some light on the decisions need to be made within a narrow timeframe.

Parental testing can bring some solace when it is shown that the variant is inherited, or escalating of anxiety if it is shown to be de novo. And yet, inheritance of a variant from a healthy parent is no guarantee of it being benign-and the other way around. In case one of the parents is a carrier of a $\mathrm{CNV}$ with

\section{Box 1 Summary points}

1. CNVs contribute to a significant proportion of risk of developing a neurodevelopmental disorder (ND), and brought to the forefront the relevance of rare de novo and essentially private mutations in this group of disorders.

2. CNVs may impact dosage-sensitive gene expression in normal brain development or unmask recessive mutations in the other allele of the same gene.

3. A broad phenotypical spectrum, ranging from normal development, to cognitive impairment, is associated with these rearrangements.

4. Genetic and environmental additional events are likely necessary to push the neuropsychiatric phenotype beyond threshold of disease.

5. Counselling for a CNV poses a great challenge, due to the variability on penetrance and expressivity and to the uncertainty on whether a given CNV poses risk for health.

incomplete penetrance, additional attention should be devoted to not stigmatise the parent or distort the couple dynamics.

Rosenfeld and colleagues calculated empirical risks taking into account frequencies of 13 recurrent CNVs in cases and controls and confirmed an already known point: deletions are usually more penetrant events than the reciprocal duplications. The associated risk of an abnormal phenotype for distal 1q21.1del is $\sim 37 \%$ versus $\sim 29 \%$ for duplications; $\sim 62.4 \%$ for distal 16p11.2del versus $11.2 \%$ for duplications; $46.8 \%$ for proximal $16 \mathrm{p} 11.2 \mathrm{del}$ versus $27.2 \%$ for duplications. The risk associated with $16 \mathrm{p} 13.11 \mathrm{del}$ is $13.1 \%$; the risk associated with $22 \mathrm{q} 11.2$ dup is $21.9 \%,{ }^{35}$ whereas the risk associated with the reciprocal deletion is $\sim 55 \%$, at least for SZ. ${ }^{129}$ This is useful

\section{Box 2 Translation into the clinical context}

1. Microarrays are currently considered first-tier clinical diagnostic test for individuals with autism spectrum disorders (ASD), intellectual disability (ID)/developmental delay (DD) or multiple congenital abnormalities (CAs).

2. Risk-associated recurrent CNVs are nowadays an unavoidable element in the clinical context in paediatrics, neurology and psychiatry and should be addressed by a multidisciplinary clinical team, including a clinical geneticist.

3. The recognition of the incomplete penetrance and variable expressivity is needed in order to assemble the relevant information for counselling.

4. Penetrance and variable expressivity of CNVs might be influenced by other genetic, epigenetic and environmental factors. Taking relatives as proxies for predicting prognosis may be useful.

5. Revisiting the literature on a regular basis is mandatory in a field of exponentially growing knowledge.

6. Risk-associated CNVs in a prenatal diagnosis context should be approached cautiously with a strategy that includes parental testing and psychological profiling and takes into account family history, pregnancy history, parental resilience, capability of accepting increased risk, religious beliefs, ethical orientations and socioeconomic support network. 


\section{Box 3 Future perspectives}

1. Further gene expression assays (either using lymphoblastoid cell lines or postmortem brain samples) are necessary to address the impact of CNVs in dosage-sensitive gene expression in normal brain development.

2. Functional analysis using animal models and/or human induced pluripotent stem cells (hiPSCs) are important for the deeper understanding of pathogenic mechanisms and for the development of new therapeutic strategies.

3. The complete characterisation (including genetic and environmental aspects) of: (A) large groups of patients with a given CNV and; (B) large cohorts of control individuals carrying the same CNV, will hopefully give some insights concerning the additional events necessary to push the neuropsychiatric phenotype beyond threshold of disease.

4. As the Encyclopedia of DNA Elements (ENCODE) project moves forward, different genome elements, including 'non-coding' sections of the genome, will be better defined, characterised and integrated in order to assess their roles in human biology and disease.

information as a $\sim 10 \%$ risk of neurodevelopmental problems associated with a $15 \mathrm{q} 11.2$ deletion is more reassuring than the $\sim 50 \%$ risk associated with a $16 \mathrm{p} 11.2$ proximal deletion. ${ }^{35}$

Still, these numbers should be approached cautiously and take into account family history, pregnancy history, parental resilience, capability of accepting increased risk, religious beliefs, ethical orientations and socioeconomical network of support (boxes 1-3).

Care should be taken to avoid psychological harm to carriers (feelings of blame and low self-esteem) and their families (discrimination of an entire branch or community). Multiple counselling sessions with several relatives are needed to evaluate who is at risk and to reinforce the meaning of arid statistical concepts. When emotional stress overpowers reasoning, psychotherapeutic follow-up may be beneficial.

Correction notice This article has been corrected since it published Online First. The first paragraph has been corrected under the 'Carriers, controls and general population' heading.

Contributors FT planned and drafted the article (except the sections concerning translation to clinical context and genetic counselling) and revised the article. MB drafted the sections concerning translation to clinical context and genetic counselling and revised the article. PM planned, drafted and critically revised the article. All authors agreed to and approved the final version.

Funding This work was supported by FEDER through the Programa Operacional Factores de Competitividade - COMPETE and by Portuguese national funds through the FCT_Fundação para a Ciência e Tecnologia, grants number PIC/IC/83026/2007 and PIC/IC/83013/2007, and PhD scholarship grant to MB, number SFRH/BDINT/ 51549/2011.

Competing interests None declared.

Provenance and peer review Commissioned; externally peer reviewed.

\section{REFERENCES}

1 American Psychiatric Association. Diagnostic and statistical manual of mental disorders: DSM-5. 5th edn. Arlington, VA: American Psychiatric Publishing, 2013.

2 Lewis DA, Levitt P. Schizophrenia as a disorder of neurodevelopment. Annu Rev Neurosci 2002;25:409-32.

3 Coe BP, Girirajan S, Eichler EE. The genetic variability and commonality of neurodevelopmental disease. Am J Med Genet C Semin Med Genet 2012;160C:118-29.

4 Manolio TA, Collins FS, Cox NJ, Goldstein DB, Hindorff LA, Hunter DJ, Mccarthy MI, Ramos EM, Cardon LR, Chakravarti A, Cho JH, Guttmacher AE, Kong A,
Kruglyak L, Mardis E, Rotimi CN, Slatkin M, Valle D, Whittemore AS, Boehnke M, Clark AG, Eichler EE, Gibson G, Haines JL, Mackay TF, McCarroll SA, Visscher PM. Finding the missing heritability of complex diseases. Nature 2009;461:747-53.

5 Malhotra D, Sebat J. CNVs: harbingers of a rare variant revolution in psychiatric genetics. Cell 2012;148:1223-41.

6 Bodmer W, Bonilla C. Common and rare variants in multifactorial susceptibility to common diseases. Nat Genet 2008;40:695-701.

7 Gaugler T, Klei L, Sanders SJ, Bodea CA, Goldberg AP, Lee AB, Mahajan M, Manaa D, Pawitan Y, Reichert J, Ripke S, Sandin S, Sklar P, Svantesson O, Reichenberg A, Hultman CM, Devlin B, Roeder K, Buxbaum JD. Most genetic risk for autism resides with common variation. Nat Genet 2014;46:881-5.

8 Redon R, Ishikawa S, Fitch KR, Feuk L, Perry GH, Andrews TD, Fiegler H, Shapero MH, Carson AR, Chen W, Cho EK, Dallaire S, Freeman JL, González JR, Gratacòs M, Huang J, Kalaitzopoulos D, Komura D, MacDonald JR, Marshall CR, Mei R, Montgomery L, Nishimura K, Okamura K, Shen F, Somerville MJ, Tchinda J, Valsesia A, Woodwark C, Yang F, Zhang J, Zerjal T, Zhang J, Armengol L, Conrad DF, Estivill X, Tyler-Smith C, Carter NP, Aburatani H, Lee C, Jones KW, Scherer SW, Hurles ME. Global variation in copy number in the human genome. Nature 2006;444:444-54.

9 Ionita-Laza I, Rogers AJ, Lange C, Raby BA, Lee C. Genetic association analysis of copy-number variation (CNV) in human disease pathogenesis. Genomics 2009;93:22-6.

10 Girirajan S, Johnson RL, Tassone F, Balciuniene J, Katiyar N, Fox K, Baker C, Srikanth A, Yeoh KH, Khoo SJ, Nauth TB, Hansen R, Ritchie M, Hertz-Picciotto I, Eichler EE, Pessah IN, Selleck SB. Global increases in both common and rare copy number load associated with autism. Hum Mol Genet 2013;22:2870-80.

11 Morrow EM. Genomic copy number variation in disorders of cognitive development. J Am Acad Child Adolesc Psychiatry 2010;49:1091-104.

12 Cooper GM, Coe BP, Girirajan S, Rosenfeld JA, Vu T, Baker C, Williams C, Stalker $H$, Hamid R, Hannig V, Abdel-Hamid H, Bader P, Mccracken E, Niyazov D, Leppig K, Thiese H, Hummel M, Alexander N, Gorski J, Kussmann J, Shashi V, Johnson K, Ballif BC, Shaffer LG, Eichler EE. A copy number variation morbidity map of developmental delay. Nat Genet 2011;43:838-46.

13 Mefford HC, Yendle SC, Hsu C, Cook J, Geraghty E, Mcmahon JM, Eeg-Olofsson O, Sadleir LG, Gill D, Zeev-Ben B, Lerman-sagie T, Mackay M, Freeman JL, Andermann E, Pelakanos J, Andrews I, Wallace G, Eichler EE, Berkovic SF, Scheffer IE. Rare copy number variants are an important cause of epileptic encephalopathies. Ann Neurol 2011;70:974-85.

14 Mullen SA, Carvill GL, Bellows S, Bayly MA, Berkovic SF, Dibbens LM, Scheffer IE, Mefford HC. Copy number variants are frequent in genetic generalized epilepsy with intellectual disability. Neurology 2013;81:1507-14.

15 Priebe L, Degenhardt FA, Herms S, Haenisch B, Mattheisen M, Nieratschker $V$, Weingarten M, Witt S, Breuer R, Paul T, Alblas M, Moebus S, Lathrop M, Leboyer M, Schreiber S, Grigoroiu-Serbanescu M, Maier W, Propping P, Rietschel M, Nöthen MM, Cichon S, Mühleisen TW. Genome-wide survey implicates the influence of copy number variants (CNVs) in the development of early-onset bipolar disorder. Mol Psychiatry 2012;17:421-32.

16 Pinto D, Pagnamenta AT, Klei L, Anney R, Merico D, Regan R, Conroy J, Magalhaes TR, Correia C, Abrahams BS, Almeida J, Bacchelli E, Bader GD, Bailey AJ, Baird G, Battaglia A, Berney T, Bolshakova N, Bölte S, Bolton PF, Bourgeron T, Brennan S, Brian J, Bryson SE, Carson AR, Casallo G, Casey J, Cochrane L, Corsello C, Crawford EL, Crossett A, Dawson G, de Jonge M, Delorme R, Drmic I, Duketis E, Duque F, Estes A, Farrar P, Fernandez BA, Filipa A, Folstein SE, Fombonne E, Freitag CM, Gilbert J, Gillberg C, Glessner JT, Goldberg J, Green A, Green J, Guter SJ, Hakonarson H, Heron EA, Hill M, Holt R, Howe JL, Hughes G, Hus V, Igliozzi R, Kim C, Klauck SM, Kolevzon A, Korvatska O, Kustanovich V, Lajonchere CM, Lamb JA, Laskawiec M, Leboyer M, Le Couteur A, Leventhal BL, Lionel AC, Liu X-Q, Lord C, Lotspeich L, Lund SC, Maestrini E, Mahoney W, Mantoulan C, Marshall CR, McConachie H, McDougle CJ, McGrath J, McMahon WM, Merikangas A, Migita O, Minshew NJ, Mirza GK, Munson J, Nelson SF, Noakes C, Noor A, Nygren G, Oliveira G, Papanikolaou K, Parr JR, Parrini B, Paton T, Pickles A, Pilorge M, Piven J, Ponting CP, Posey DJ, Poustka A, Poustka F, Prasad A, Ragoussis J, Renshaw K, Rickaby J, Roberts W, Roeder K, Roge B, Rutter ML, Bierut L, Rice JP, Consortium-SAGE, Salt J, Sansom K, Sato D, Segurado R, Senman L, Shah N, Sheffield VC, Soorya L, Sousa I, Stein O, Stoppioni V, Strawbridge C, Tancredi R, Tansey K, Thiruvahindrapuram B, Thompson AP, Thomson S, Tryfon A, Tsiantis J, Van Engeland H, Vincent JB, Volkmar F, Wallace S, Wang K, Wang Z, Wassink TH, Webber C, Wing K, Wittemeyer K, Wood S, Wu J, Yaspan BL, Zurawiecki D, Zwaigenbaum L, Buxbaum JD, Cantor RM, Cook EH, Coon H, Cuccaro ML, Devlin B, Ennis S, Gallagher L. Functional impact of global rare copy number variation in autism spectrum disorders. Nature 2010;466:368-72.

17 Levy D, Ronemus M, Yamrom B, Lee Y, Leotta A, Kendall J, Marks S, Lakshmi B, Pai D, Ye K, Buja A, Krieger A, Yoon S, Troge J, Rodgers L, lossifov I, Wigler M. Rare de novo and transmitted copy-number variation in autistic spectrum disorders. Neuron 2011;70:886-97.

18 Sanders SJ, Ercan-Sencicek AG, Hus V, Luo R, Murtha MT, Moreno-De-Luca D, Chu SH, Moreau MP, Gupta AR, Thomson SA, Mason CE, Bilguvar K, 
Celestino-Soper PBS, Choi M, Crawford EL, Davis L, Davis Wright NR, Dhodapkar RM, DiCola M, DiLullo NM, Fernandez TV, Fielding-Singh V, Fishman DO, Frahm S, Garagaloyan R, Goh GS, Kammela S, Klei L, Lowe JK, Lund SC, McGrew AD, Meyer KA, Moffat WJ, Murdoch JD, O'Roak BJ, Ober GT, Pottenger RS, Raubeson MJ, Song Y, Wang Q, Yaspan BL, Yu TW, Yurkiewicz IR, Beaudet AL, Cantor RM, Curland M, Grice DE, Gunel M, Lifton RP, Mane SM, Martin DM, Shaw CA, Sheldon M, Tischfield JA, Walsh CA, Morrow EM, Ledbetter DH, Fombonne E, Lord C, Martin CL, Brooks Al, Sutcliffe JS, Cook EH, Geschwind D, Roeder K, Devlin B, State MW. Multiple recurrent De Novo CNVs, including duplications of the $7 q 11.23$ Williams syndrome region, are strongly associated with autism. Neuron 2011;70:863-85.

19 Sebat J, Levy DL, McCarthy S. Rare structural variants in schizophrenia: one disorder, multiple mutations; one mutation, multiple disorders. Trends Genet 2009;25:528-35.

20 Williams NM, Franke B, Mick E, Anney RJL, Freitag CM, Gill M, Thapar A, O'Donovan MC, Owen MJ, Holmans P, Kent L, Middleton F, Yanli Z-J, Liu L, Meyer J, Nguyen TT, Romanos J, Romanos M, Seitz C, Renner TJ, Walitza S, Warnke A, Haukur P, Buitelaar J, Rommelse N, Vasquez AA, Hawi Z, Langley K, Sergeant J, Steinhausen H-C, Roeyers H, Biederman J, Zaharieva I, Hakonarson $H$, Elia J, Lionel AC, Crosbie J, Marshall CR, Schachar R, Scherer SW, Todorov A, Smalley SL, Loo S, Nelson S, Shtir C, Asherson P, Reif A, Lesch K-P, Faraone SV. Genome-wide analysis of copy number variants in attention deficit disorder: the role of rare variants and duplications at $15 q 13.3$. Am J Psychiatry 2012;169:195-204.

21 Stranger BE, Forrest MS, Dunning M, Ingle CE, Beazley $C$, Thorne N, Redon R, Bird CP, de Grassi A, Lee C, Tyler-Smith C, Carter N, Scherer SW, Tavaré S, Deloukas P, Hurles ME, Dermitzakis ET. Relative impact of nucleotide and copy number variation on gene expression phenotypes. Science 2007:315:848-53.

22 Schlattl A, Anders S, Waszak SM, Huber W, Korbel JO. Relating CNVs to transcriptome data at fine resolution: Assessment of the effect of variant size, type, and overlap with functional regions. Genome Res 2011;21:2004-13.

23 Luo R, Sanders SJ, Tian Y, Voineagu I, Huang N, Chu SH, Klei L, Cai C, Ou J, Lowe JK, Hurles ME, Devlin B, State MW, Geschwind DH. Genome-wide transcriptome profiling reveals the functional impact of rare de novo and recurrent CNVs in autism spectrum disorders. Am J Hum Genet 2012;91:38-55.

24 Ye T, Lipska BK, Tao R, Hyde TM, Wang L, Li C, Choi KH, Straub RE, Kleinman JE, Weinberger DR. Analysis of copy number variations in Brain DNA from patients with schizophrenia and other psychiatric disorders. Biol Psychiatry 2012;72:651-4.

25 Mehta D, Iwamoto K, Ueda J, Bundo M, Adati N, Kojima T, Kato T. Comprehensive survey of CNVs influencing gene expression in the human brain and its implications for pathophysiology. Neurosci Res 2014;79:22-33.

26 Mefford HC, Sharp A, Baker C, Itsara A, Jiang Z, Buysse K, Huang S, Maloney V, Crolla J, Baralle D, Collins A, Mercer C, Norga K, de Ravel T, Devriendt K, Bongers E, de Leeuw N, Reardon W, Gimelli S, Bena F, Hennekam RC, Male A, Gaunt L, Clayton-Smith J, Simonic I, Park SM, Mehta SG, Nik-Zainal S, Woods C, Firth HV, Parkin G, Fichera M, Reitano S, Lo Giudice M, Li KE, Casuga I, Broomer A, Conrad B, Schwerzmann M, Räber L, Gallati S, Striano P, Coppola A, Tolmie JL, Tobias ES, Lilley C, Armengol L, Spysschaert Y, Verloo P, De Coene A, Goossens L, Mortier G, Speleman F, van Binsbergen E, Nelen MR, Hochstenbach R, Poot $M$, Gallagher L, Gill M, McClellan J, King M-C, Regan R, Skinner C, Stevenson RE, Antonarakis SE, Chen C, Estivill X, Menten B, Gimelli G, Gribble S, Schwartz S, Sutcliffe JS, Walsh T, Knight SJL, Sebat J, Romano C, Schwartz CE, Veltman J, de Vries B, Vermeesch JR, Barber JCK, Willatt L, Tassabehji M, Eichler EE. Recurrent rearrangements of chromosome 1q21.1 and variable pediatric phenotypes. $N$ Engl J Med 2008;359:1685-99.

27 Kaminsky EB, Kaul V, Paschall J, Church DM, Bunke B, Kunig D, Moreno-de-Luca D, Moreno-de-Luca A, Mulle JG, Warren ST, Richard G, Compton JG, Fuller AE, Gliem TJ, Huang S, Collinson MN, Beal SJ, Ackley T, Pickering DL, Golden DM, Aston E, Whitby H, Shetty S, Rossi MR, Rudd MK, South ST, Brothman AR, Sanger WG, Iyer RK, Crolla JA, Thorland EC, Aradhya S, Ledbetter DH, Martin CL. An evidence-based approach to establish the functional and clinical significance of copy number variants in intellectual and developmental disabilities. Genet Med 2011;13:777-84

28 Stefansson $H$, Rujescu D, Cichon S, Pietiläinen OPH, Ingason A, Steinberg $S$, Fossdal R, Sigurdsson E, Sigmundsson T, Buizer-Voskamp JE, Hansen T, Jakobsen KD, Muglia P, Francks C, Matthews PM, Gylfason A, Halldorsson BV, Gudbjartsson $D$, Thorgeirsson TE, Sigurdsson A, Jonasdottir A, Jonasdottir A, Bjornsson A, Mattiasdottir S, Blondal T, Haraldsson M, Magnusdottir BB, Giegling I, Moller H-J, Hartmann AM, Shianna KV, Ge D, Need AC, Crombie C, Fraser G, Walker N, Lonnqvist J, Suvisaari J, Tuulio-Henriksson A, Paunio T, Toulopoulou T, Bramon E, Di Forti M, Murray R, Ruggeri M, Vassos E, Tosato S, Walshe M, Li T, Vasilescu C, Muhleisen TW, Wang AG, Ullum H, Djurovic S, Melle I, Olesen J, Kiemeney LA, Franke B, GROUP, Kahn RS, Linszen DH, van Os J, Wiersma D, Bruggeman R, Cahn W, de Haan L, Krabbendam L, Myin-Germeys I, Sabatti C, Freimer NB, Gulcher JR, Thorsteinsdóttir U, Kong A, Andreassen OA, Ophoff RA, Georgi A, Rietschel M, Werge T, Petursson H, Goldstein DB, Nothen MM, Peltonen L, Collier DA, St Clair D, Stefansson K. Large recurrent microdeletions associated with schizophrenia. Nature 2008;455:232-6.
29 Kirov G, Grozeva D, Norton N, Ivanov D, Mantripragada KK, Holmans P, Craddock $\mathrm{N}$, Owen MJ, O'Donovan MC. Support for the involvement of large copy number variants in the pathogenesis of schizophrenia. Hum Mol Genet 2009:18:1497-503.

30 Levinson DF, Duan J, Oh S, Wang K, Sanders AR, Shi J, Zhang N, Mowry BJ, Olincy A, Amin F, Cloninger CR, Silverman JM, Buccola NG, Byerley WF, Black DW, Kendler KS, Freedman R, Dudbridge F, Pe'er I, Hakonarson H, Bergen SE, Fanous AH, Holmans PA, Gejman PV. Copy number variants in schizophrenia: confirmation of five previous findings and new evidence for 3q29 microdeletions and VIPR2 duplications. Am J Psychiatry 2011;168:302-16.

31 Rees E, Walters JTR, Georgieva L, Isles AR, Chambert KD, Richards AL, Mahoney-Davies G, Legge SE, Moran JL, McCarroll SA, O'Donovan MC, Owen MJ, Kirov $\mathrm{G}$. Analysis of copy number variations at 15 schizophrenia-associated loci. $\mathrm{Br}$ J Psychiatry 2014;204:108-14.

32 Mulle JG, Dodd AF, McGrath JA, Wolyniec PS, Mitchell AA, Shetty AC, Sobreira NL, Valle D, Rudd MK, Satten G, Cutler DJ, Pulver AE, Warren ST. Microdeletions of 3q29 confer high risk for schizophrenia. Am J Hum Genet 2010;87:229-36.

33 de Kovel CGF, Trucks H, Helbig I, Mefford HC, Baker C, Leu C, Kluck C, Muhle H, Von Spiczak S, Ostertag P, Obermeier T, Kleefuss-Lie AA, Hallmann K, Steffens M, Gaus V, Klein KM, Hamer HM, Rosenow F, Brilstra EH, Kasteleijn-Nolst Trenité D, Swinkels MEM, Weber YG, Unterberger I, Zimprich F, Urak L, Feucht M, Fuchs K, Moller RS, Hjalgrim H, De Jonghe P, Suls A, Ruckert IM, Wichmann HE, Franke A, Schreiber S, Nurnberg P, Elger CE, Lerche H, Stephani U, Koeleman BPC, Lindhout D, Eichler EE, Sander T. Recurrent microdeletions at 15q11.2 and 16p13.11 predispose to idiopathic generalized epilepsies. Brain 2010;133:23-32.

34 Mefford HC, Cooper GM, Zerr T, Smith JD, Baker C, Shafer N, Thorland EC, Skinner C, Schwartz CE, Nickerson DA, Eichler EE. A method for rapid, targeted CNV genotyping identifies rare variants associated with neurocognitive disease. Genome Res 2009;19:1579-85.

35 Rosenfeld JA, Coe BP, Eichler EE, Cuckle H, Phil D, Shaffer LG. Estimates of penetrance for recurrent pathogenic copy-number variations. Genet Med 2013;15:478-81.

36 Burnside RD, Pasion R, Mikhail FM, Carroll AJ, Robin NH, Youngs EL, Gadi IK, Keitges E, Jaswaney VL, Papenhausen PR, Potluri VR, Risheg H, Rush B, Smith JL, Schwartz S, Tepperberg JH, Butler MG. Microdeletion/microduplication of proximal $15 q 11.2$ between BP1 and BP2: a susceptibility region for neurological dysfunction including developmental and language delay. Hum Genet 2011;130:517-28.

37 Leblond CS, Heinrich J, Delorme R, Proepper C, Betancur C, Huguet G, Konyukh $M$, Chaste $P$, Ey E, Rastam M, Anckarsäter H, Nygren G, Gillberg IC, Melke J, Toro $R$, Regnault $B$, Fauchereau $F$, Mercati $O$, Lemière $N$, Skuse $D$, Poot $M$, Holt $R$, Monaco AP, Järvelä I, Kantojärvi K, Vanhala R, Curran S, Collier DA, Bolton P Chiocchetti A, Klauck SM, Poustka F, Freitag CM, Waltes R, Kopp M, Duketis E, Bacchelli E, Minopoli F, Ruta L, Battaglia A, Mazzone L, Maestrini E, Sequeira AF, Oliveira B, Vicente A, Oliveira G, Pinto D, Scherer SW, Zelenika D, Delepine M, Lathrop M, Bonneau D, Guinchat V, Devillard F, Assouline B, Mouren MC, Leboyer M, Gillberg C, Boeckers TM, Bourgeron T. Genetic and functional analyses of SHANK2 mutations suggest a multiple hit model of autism spectrum disorders. PLOS Genet 2012;8:e1002521.

38 De Wolf V, Brison N, Devriendt K, Peeters H. Genetic counseling for susceptibility loci and neurodevelopmental disorders: the del15q11.2 as an example. Am J Med Genet A 2013;161A:2846-54.

39 Helbig I, Mefford HC, Sharp AJ, Guipponi M, Fichera M, Franke A, Muhle H, de Kovel C, Baker C, von Spiczak S, Kron KL, Steinich I, Kleefuss-Lie AA, Leu C, Gaus $V$, Schmitz B, Klein KM, Reif PS, Rosenow F, Weber $Y$, Lerche $H$, Zimprich F, Urak L, Fuchs K, Feucht M, Genton P, Thomas P, Visscher F, de Haan G-J, Møller RS, Hjalgrim $H$, Luciano D, Wittig M, Nothnagel M, Elger CE, Nurnberg P, Romano C, Malafosse A, Koeleman BPC, Lindhout D, Stephani U, Schreiber S, Eichler EE, Sander T. 15q13.3 microdeletions increase risk of idiopathic generalized epilepsy. Nat Genet 2009;41:160-2.

40 Dibbens LM, Mullen S, Helbig I, Mefford HC, Bayly MA, Bellows S, Leu C, Trucks $H$, Obermeier T, Wittig M, Franke A, Caglayan H, Yapici Z, EPICURE-Consortium, Sander T, Eichler EE, Scheffer IE, Mulley JC, Berkovic SF. Familial and sporadic $15 q 13.3$ microdeletions in idiopathic generalized epilepsy: precedent for disorders with complex inheritance. Hum Mol Genet 2009;18:3626-31.

41 Kumar RA, KaraMohamed S, Sudi J, Conrad DF, Brune C, Badner JA, Gilliam TC, Nowak NJ, Cook EH, Dobyns WB, Christian SL. Recurrent 16p11.2 microdeletions in autism. Hum Mol Genet 2008;17:628-38.

42 Glessner JT, Wang K, Cai G, Korvatska O, Kim CE, Wood S, Zhang H, Estes A, Brune CW, Bradfield JP, Imielinski M, Frackelton EC, Reichert J, Crawford EL, Munson J, Sleiman PMA, Chiavacci R, Annaiah K, Thomas K, Hou C, Glaberson W, Flory J, Otieno F, Garris M, Soorya L, Klei L, Piven J, Meyer KJ, Anagnostou E, Sakurai T, Game RM, Rudd DS, Zurawiecki D, McDougle CJ, Davis LK, Miller J, Posey DJ, Michaels S, Kolevzon A, Silverman JM, Bernier R, Levy SE, Schultz RT, Dawson G, Owley T, McMahon WM, Wassink TH, Sweeney JA, Nurnberger Jl, Coon H, Sutcliffe JS, Minshew NJ, Grant SFA, Bucan M, Cook EH, Buxbaum JD, Devlin B, Schellenberg GD, Hakonarson $\mathrm{H}$. Autism genome-wide copy number variation reveals ubiquitin and neuronal genes. Nature 2009;459:569-73. 
43 Guha S, Rees E, Darvasi A, Ivanov D, Ikeda M, Bergen SE, Magnusson PK, Cormican P, Morris D, Gill M, Cichon S, Rosenfeld JA, Lee A, Gregersen PK, Kane $J M$, Malhotra AK, Rietschel M, Nöthen MM, Degenhardt F, Priebe L, Breuer R, Strohmaier J, Ruderfer DM, Moran JL, Chambert KD, Sanders AR, Shi J, Kendler K, Riley B, O'Neill T, Walsh D, Malhotra D, Corvin A, Purcell S, Sklar P, Iwata N, Hultman CM, Sullivan PF, Sebat J, McCarthy S, Gejman PV, Levinson DF, Owen MJ, O’Donovan MC, Lencz T, Kirov G. Implication of a rare deletion at distal 16p11.2 in schizophrenia. JAMA Psychiatry 2013;70:253-60.

44 Bachmann-Gagescu R, Mefford HC, Cowan C, Glew GM, Hing AV, Wallace S, Bader PI, Hamati A, Reitnauer PJ, Smith R, Stockton DW, Muhle H, Helbig I, Eichler EE, Ballif BC, Rosenfeld J, Tsuchiya KD. Recurrent 200-kb deletions of $16 \mathrm{p} 11.2$ that include the SH2B1 gene are associated with developmental delay and obesity. Genet Med 2010;12:641-7.

45 Hannes FD, Sharp AJ, Mefford HC, de Ravel T, Ruivenkamp CA, Breuning MH, Fryns J-P, Devriendt K, Van Buggenhout G, Vogels A, Stewart H, Hennekam RC, Cooper GM, Regan R, Knight SJL, Eichler EE, Vermeesch JR. Recurrent reciprocal deletions and duplications of 16p13.11: the deletion is a risk factor for MR/MCA while the duplication may be a rare benign variant. J Med Genet 2009:46:223-32.

46 Ingason $A$, Rujescu D, Cichon S, Sigurdsson E, Sigmundsson T, Pietiläinen $\mathrm{OPH}$, Buizer-Voskamp JE, Strengman E, Francks C, Muglia P, Gylfason A, Gustafsson O, Olason PI, Steinberg S, Hansen T, Jakobsen KD, Rasmussen HB, Giegling I, Möller $\mathrm{H}-\mathrm{J}$, Hartmann A, Crombie C, Fraser G, Walker N, Lonnqvist J, Suvisaari J, Tuulio-Henriksson A, Bramon E, Kiemeney LA, Franke B, Murray R, Vassos E, Toulopoulou T, Mühleisen TW, Tosato S, Ruggeri M, Djurovic S, Andreassen OA, Zhang Z, Werge T, Ophoff RA, Rietschel M, Nöthen MM, Petursson H, Stefansson H, Peltonen L, Collier D, Stefansson K, St Clair DM. Copy number variations of chromosome 16p13.1 region associated with schizophrenia. Mol Psychiatry 2009;16:1-9.

47 Heinzen EL, Radtke RA, Urban TJ, Cavalleri GL, Depondt C, Need AC, Walley NM, Nicoletti P, Ge D, Catarino CB, Duncan JS, Kasperavičiute D, Tate SK, Caboclo LO, Sander JW, Clayton L, Linney KN, Shianna KV, Gumbs CE, Smith J, Cronin KD, Maia JM, Doherty CP, Pandolfo M, Leppert D, Middleton LT, Gibson RA, Johnson MR, Matthews PM, Hosford D, Kälviäinen R, Eriksson K, Kantanen AM, Dorn T, Hansen J, Krämer G, Steinhoff BJ, Wieser HG, Zumsteg D, Ortega M, Wood NW, Huxley-Jones J, Mikati M, Gallentine WB, Husain AM, Buckley PG, Stallings RL, Podgoreanu MV, Delanty N, Sisodiya SM, Goldstein DB. Rare Deletions at 16p13.11 Predispose to a Diverse Spectrum of Sporadic Epilepsy Syndromes. Am J Hum Genet 2010;86:707-18.

48 Williams NM, Zaharieva I, Martin A, Langley K, Mantripragada K, Fossdal R, Stefansson H, Stefansson K, Magnusson P, Gudmundsson 00, Gustafsson O, Holmans P, Owen MJ, O'Donovan M, Thapar A. Rare chromosomal deletions and duplications in attention-deficit hyperactivity disorder: a genome-wide analysis. Lancet 2010;376:1401-8.

49 Kim H-G, Kishikawa S, Higgins AW, Seong I-S, Donovan DJ, Shen Y, Lally E, Weiss LA, Najm J, Kutsche K, Descartes M, Holt L, Braddock S, Troxell R, Kaplan L, Volkmar F, Klin A, Tsatsanis K, Harris DJ, Noens I, Pauls DL, Daly MJ, Macdonald ME, Morton CC, Quade BJ, Gusella JF. Disruption of Neurexin 1 associated with autism spectrum disorder. Am J Hum Genet 2008;82:199-207.

50 Hedges DJ, Hamilton-Nelson KL, Sacharow SJ, Nations L, Beecham GW, Kozhekbaeva ZM, Butler BL, Cukier HN, Whitehead PL, Ma D, Jaworski JM, Nathanson L, Lee JM, Hauser SL, Oksenberg JR, Cuccaro ML, Haines JL, Gilbert JR, Pericak-Vance MA. Evidence of novel fine-scale structural variation at autism spectrum disorder candidate loci. Mol Autism 2012;3:1-11.

51 Kirov G, Rujescu D, Ingason A, Collier DA, O'Donovan MC, Owen MJ. Neurexin 1 (NRXN1) deletions in schizophrenia. Schizophr Bull 2009;35:851-4.

52 Coe BP, Witherspoon K, Rosenfeld JA, van Bon BWM, Vulto-van Silfhout AT, Bosco P, Friend KL, Baker C, Buono S, Vissers LELM, Schuurs-Hoeijmakers JH, Hoischen A, Pfundt R, Krumm N, Carvill GL, Li D, Amaral D, Brown N, Lockhart PJ, Scheffer IE, Alberti A, Shaw M, Pettinato R, Tervo R, de Leeuw N, Reijnders MRF, Torchia BS, Peeters H, Thompson E, O'Roak BJ, Fichera M, Hehir-Kwa JY, Shendure J, Mefford HC, Haan E, Gécz J, de Vries BBA, Romano C, Eichler EE. Refining analyses of copy number variation identifies specific genes associated with developmental delay. Nat Genet 2014;46:1063-71.

53 Fernandez T, Morgan T, Davis N, Klin A, Morris A, Farhi A, Lifton RP, State MW. Disruption of Contactin 4 (CNTN4) results in developmental delay and other features of 3p deletion syndrome. Am J Hum Genet 2004;74: 1286-93.

54 Roohi J, Montagna C, Tegay DH, Palmer LE, DeVincent C, Pomeroy JC, Christian SL, Nowak N, Hatchwell E. Disruption of contactin 4 in three subjects with autism spectrum disorder. J Med Genet 2009;46:176-82.

55 Leblond CS, Nava C, Polge A, Gauthier J, Huguet G, Lumbroso S, Giuliano F, Stordeur C, Depienne C, Mouzat K, Pinto D, Howe J, Lemière N, Durand CM, Guibert J, Ey E, Toro R, Peyre H, Mathieu A, Amsellem F, Rastam M, Gillberg IC, Rappold GA, Holt R, Monaco AP, Maestrini E, Galan P, Heron D, Jacquette A, Afenjar A, Rastetter A, Brice A, Devillard F, Assouline B, Laffargue F, Lespinasse J, Chiesa J, Rivier F, Bonneau D, Regnault B, Zelenika D, Delepine M, Lathrop M, Sanlaville D, Schluth-Bolard C, Edery P, Perrin L, Tabet AC, Schmeisser MJ,
Boeckers TM, Coleman M, Sato D, Szatmari P, Scherer SW, Rouleau GA, Betancur C, Leboyer M, Gillberg C, Delorme R, Bourgeron T. Meta-analysis of SHANK mutations in autism spectrum disorders: a gradient of severity in cognitive impairments. PLOS Genet 2014;10:1-15.

56 Kirov G, Pocklington AJ, Holmans P, Ivanov D, Ikeda M, Ruderfer D, Moran J, Chambert K, Toncheva D, Georgieva L, Grozeva D, Fjodorova M, Wollerton R, Rees E, Nikolov I, van de Lagemaat LN, Bayés A, Fernandez E, Olason PI, Böttcher Y, Komiyama NH, Collins MO, Choudhary J, Stefansson K, Stefansson H, Grant SGN, Purcell S, Sklar P, O'Donovan MC, Owen MJ. De novo CNV analysis implicates specific abnormalities of postsynaptic signalling complexes in the pathogenesis of schizophrenia. Mol Psychiatry 2012;17:142-53.

57 Mulle JG, Pulver AE, McGrath JA, Wolyniec PS, Dodd AF, Cutler DJ, Sebat J, Malhotra D, Nestadt G, Conrad DF, Hurles M, Barnes CP, Ikeda M, Iwata N, Levinson DF, Gejman PV, Sanders AR, Duan J, Mitchell AA, Peter I, Sklar P, O'Dushlaine CT, Grozeva D, O'Donovan MC, Owen MJ, Hultman CM, Kähler AK, Sullivan PF, Schizophrenia-Consortium, Kirov G, Warren ST. Reciprocal duplication of the Williams-Beuren syndrome deletion on chromosome 7q11.23 is associated with schizophrenia. Biol Psychiatry 2014;75:371-7.

58 Rosenfeld JA, Traylor RN, Schaefer GB, McPherson EW, Ballif BC, Klopocki E, Mundlos S, Shaffer LG, Aylsworth AS. Proximal microdeletions and microduplications of 1q21.1 contribute to variable abnormal phenotypes. Eur J Hum Genet 2012;20:754-61.

59 Brunetti-Pierri N, Berg JS, Scaglia F, Belmont J, Bacino CA, Sahoo T, Lalani SR, Graham B, Lee B, Shinawi M, Shen J, Kang SL, Pursley A, Lotze T, Kennedy G, Lansky-Shafer $S$, Weaver $C$, Roeder ER, Grebe TA, Arnold GL, Hutchison T, Reimschisel T, Amato S, Geragthy MT, Innis JW, Obersztyn E, Nowakowska B, Rosenberg SS, Bader PI, Grange DK, Naqvi S, Garnica AD, Bernes SM, Fong C-T, Summers A, Walters WD, Lupski JR, Stankiewicz P, Cheung SW, Patel A. Recurrent reciprocal 1q21.1 deletions and duplications associated with microcephaly or macrocephaly and developmental and behavioral abnormalities. Nat Genet 2008;40:1466-71.

60 Harvard C, Strong E, Mercier E, Colnaghi R, Alcantara D, Chow E, Martell S, Tyson C, Hrynchak M, McGillivray B, Hamilton S, Marles S, Mhanni A, Dawson AJ, Pavlidis P, Qiao Y, Holden JJ, Lewis SME, O'Driscoll M, Rajcan-Separovic E. Understanding the impact of 1q21.1 copy number variant. Orphanet J Rare Dis 2011;6:54.

61 Dasgupta B, Milbrandt J. AMP-activated protein kinase phosphorylate retinoblastoma protein to control mammalian brain development. Dev Cell 2009;16:256-70.

62 Van Bon BWM, Mefford HC, de Vries BBA. 15q13.3 microdeletion. In: Pagon RA, Adam M, Ardinger HH, Wallace SE, Amemiya A, Bean LJH, Bird TD, Fong CT, Mefford HC, Smith RJH, Stephens K, editors. GeneReviews ®nternet. Seattle: University of Washington, 2010.

63 Ballif BC, Theisen A, Coppinger J, Gowans GC, Hersh JH, Madan-Khetarpal S, Schmidt KR, Tervo R, Escobar LF, Friedrich CA, McDonald M, Campbell L, Ming JE, Zackai EH, Bejjani BA, Shaffer LG. Expanding the clinical phenotype of the 3q29 microdeletion syndrome and characterization of the reciprocal microduplication. Mol Cytogenet 2008;1:1-7.

64 Quintero-Rivera F, Sharifi-Hannauer P, Martinez-Agosto JA. Autistic and psychiatric findings associated with the $3 q 29$ microdeletion syndrome: case report and review. Am J Med Genet A 2010;152A:2459-67.

65 Wang C, Koide T, Kimura H, Kunimoto S, Yoshimi A, Nakamura Y, Kushima I, Banno M, Kawano N, Takasaki Y, Xing J, Noda Y, Mouri A, Aleksic B, Ikeda M, Okada T, lidaka T, Inada T, Iwata N, Ozaki N. Novel rare variants in F-box protein 45 (FBX045) in schizophrenia. Schizophr Res 2014;157:149-56.

66 Mefford HC, Mulley JC. Genetically complex epilepsies, copy number variants and syndrome constellations. Genome Med 2010;2:1-8.

67 Jähn JA, von Spiczak S, Muhle H, Obermeier T, Franke A, Mefford HC, Stephani U, Helbig I. Iterative phenotyping of 15q11.2, 15q13.3 and 16p13.11 microdeletion carriers in pediatric epilepsies. Epilepsy Res 2014;108:109-16.

68 Goytain A, Hines RM, El-Husseini A, Quamme GA. NIPA1(SPG6), the basis for autosomal dominant form of hereditary spastic paraplegia, encodes a functional Mg2+ transporter. J Biol Chem 2007;282:8060-8.

69 Goytain A, Hines RM, Quamme GA. Functional characterization of NIPA2, a selective Mg2+ transporter. Am J Physiol Cell Physiol 2008;295:C944-53.

70 Rainier S, Chai J, Tokarz D, Nicholls RD, Fink JK. NIPA1 Gene Mutations Cause Autosomal Dominant Hereditary Spastic Paraplegia (SPG6). Am J Hum Genet 2003;73:967-71.

71 Jiang Y, Zhang Y, Zhang P, Sang T, Zhang F, Ji T, Huang Q, Xie H, Du R, Cai B, Zhao H, Wang J, Wu Y, Wu H, Xu K, Liu X, Chan P, Wu X. NIPA2 located in $15 q 11.2$ is mutated in patients with childhood absence epilepsy. Hum Genet 2012;131:1217-24.

72 Napoli I, Mercaldo V, Boyl PP, Eleuteri B, Zalfa F, De Rubeis S, Di Marino D, Mohr E, Massimi M, Falconi M, Witke W, Costa-Mattioli M, Sonenberg N, Achsel T, Bagni C. The Fragile X Syndrome Protein Represses Activity-Dependent Translation through CYFIP1, a New 4E-BP. Cell 2008;134:1042-54.

73 De Rubeis $S$, Bagni C. Regulation of molecular pathways in the Fragile $X$ Syndrome: insights into Autism Spectrum Disorders. I Neurodev Disord 2011;3:257-69. 
74 Pathania M, Davenport EC, Muir J, Sheehan DF, López-Doménech G, Kittler JT. The autism and schizophrenia associated gene CYFIP1 is critical for the maintenance of dendritic complexity and the stabilization of mature spines. Trans/ Psychiatry 2014;4:1-11.

75 Murphy SM, Preble AM, Patel UK, O'Connell KL, Dias DP, Moritz M, Agard D, Stults JT, Stearns T. GCP5 and GCP6: two new members of the human gamma-tubulin complex. Mol Biol Cell 2001;12:3340-52.

76 Sharp AJ, Mefford HC, Li K, Baker C, Skinner C, Stevenson RE, Schroer RJ, Novara F, de Gregori M, Ciccone R, Broomer A, Casuga I, Wang Y, Xiao C, Barbacioru C, Gimelli G, Bernardina BD, Torniero C, Giorda R, Regan R, Murday V, Mansour S, Fichera M, Castiglia L, Failla P, Ventura M, Jiang Z, Cooper GM, Knight SJL, Romano C, Zuffardi O, Chen C, Schwartz CE, Eichler EE. A recurrent 15q13.3 microdeletion syndrome associated with mental retardation and seizures. Nat Genet 2008;40:322-8.

77 van Bon B, Mefford HC, Menten B, Koolen DA, Sharp AJ, Nillesen W, Innis JW, de Ravel T, Mercer C, Fichera M, Stewart H, Connell L, Ounap K, Lachlan K, Castle B, Van der Aa N, van Ravenswaaij C, Nobrega M, Serra-Juhé C, Somonic I, de Leeuw N, Pfundt R, Bongers EM, Baker C, Finnemore P, Huang S, Maloney VK, Crolla JA, van Kalmthout $M$, Elia $M$, Vandeweyer $G$, Fryns J-P, Janssen S, Foulds $N$, Reitano S, Smith K, Parkel S, Loeys B, Woods CG, Oostra A, Speleman F, Pereira A, Kurg A, Willatt L, Knight SJL, Vermeesch JR, Romano C, Barber JC, Mortier G, Pérez Jurado LA, Kooy RF, Brunner HG, Eichler EE, Kleefstra T, de Vries BBA. Further delineation of $15 q 13$ microdeletion and duplication syndrome: a clinical spectrum varying from non-pathogenic to a severe outcome. J Med Genet 2009;46:511-23.

78 Masurel-Paulet A, Andrieux J, Callier P, Cuisset JM, Le Caignec C, Holder M, Thauvin-Robinet C, Doray B, Flori E, Alex-Cordier MP, Beri M, Boute O, Delobel B, Dieux $A$, Vallee $L$, Jaillard $S$, Odent $S$, Isidor $B$, Beneteau $C$, Vigneron J, Bilan $F$, Gilbert-Dussardier B, Dubourg C, Labalme A, Gautier A, Pernes P, Bidon C, Pinoit JM, Huet F, Mugneret F, Aral B, Jonveaux $P$, Sanlaville D, Faivre L. Delineation of 15q13.3 microdeletions. Clin Genet 2010;78:149-61.

79 Gillentine MA, Schaaf CP. The human clinical phenotypes of altered CHRNA7 copy number. Biochem Pharmacol 2015;97:352-62.

80 Hoppman-Chaney N, Wain K, Seger PR, Superneau DW, Hodge JC. Identification of single gene deletions at $15 q 13.3$ : further evidence that CHRNA7 causes the 15q13.3 microdeletion syndrome phenotype. Clin Genet 2013;83:345-51.

81 Sinkus ML, Graw S, Freedman R, Ross RG, Lester HA, Leonard S. The human CHRNA7 and CHRFAM7A genes: A review of the genetics, regulation, and function. Neuropharmacology 2015;96:274-88.

82 Chen Z-H, Wang C, Wang L-G, Zhuo M-Q, Tang Z-H, Zhai Q-X, Chen Q, Guo Y-X, Zhang Y-X. Analysis of the CHRNA7 gene mutation and polymorphism in Southern Han Chinese patients with nocturnal frontal epilepsy. Asian Pac J Trop Med 2015;8:330-3.

83 Bacchelli E, Battaglia A, Cameli C, Lomartire S, Tancredi R, Thomson S, Sutcliffe JS, Maestrini E. Analysis of CHRNA7 rare variants in autism spectrum disorder susceptibility. Am J Med Genet A 2015;167:715-23.

84 Nasiripourdori A, Taly V, Grutter T, Taly A. From toxins targeting ligand gated ion channels to therapeutic molecules. Toxins (Basel) 2011;3:260-93.

85 Pohanka M. Alpha7 nicotinic acetylcholine receptor is a target in pharmacology and toxicology. Int J Mol Sci 2012;13:2219-38.

86 Stevens KE, Zheng L, Floyd KL, Stitzel JA. Maximizing the effect of an $\alpha 7$ nicotinic receptor PAM in a mouse model of schizophrenia-like sensory inhibition deficits. Brain Res 2015;1611:8-17.

87 Wu W-L, Adams CE, Stevens KE, Chow K-H, Freedman R, Patterson PH. The interaction between maternal immune activation and alpha 7 nicotinic acetylcholine receptor in regulating behaviors in the offspring. Brain Behav Immun 2015;46:192-202

88 Ionita-Laza I, Xu B, Makarov V, Buxbaum JD, Roos JL, Gogos JA, Karayiorgou M. Scan statistic-based analysis of exome sequencing data identifies FAN1 at 15q13.3 as a susceptibility gene for schizophrenia and autism. Proc Natl Acad Sci USA 2014;111:343-8.

89 Trujillo JP, Mina LB, Pujol R, Bogliolo M, Andrieux J, Holder M, Schuster B, Schindler D, Surrallés J. On the role of FAN1 in Fanconi anemia. Blood 2012;120:86-9.

90 Bijlsma E, Gijsbers A, Schuurs-Hoeijmakers J, van Haeringen A, Fransen van de Putte $D$, Anderlid B-M, Lundin J, Lapunzina $P$, Pérez Jurado L, Delle Chiaie B, Loeys B, Menten B, Oostra A, Verhelst $H$, Amor D, Bruno D, van Essen A, Hordijk $R$, Sikkema-Raddatz $B$, Verbruggen $K$, Jongmans $M$, Pfundt $R$, Reeser $H$, Breuning $M$, Ruivenkamp $C$. Extending the phenotype of recurrent rearrangements of 16p11.2: deletions in mentally retarded patients without autism and in normal individuals. Eur J Hum Genet 2009;52:77-87.

91 Weiss LA, Shen Y, Korn JM, Arking DE, Miller DT, Fossdal R, Saemundsen E, Stefansson H, Ferreira MAR, Green T, Platt OS, Ruderfer DM, Walsh CA, Altshuler D, Chakravarti A, Tanzi RE, Stefansson K, Santangelo SL, Gusella JF, Sklar P, Wu $\mathrm{B}$, Daly MJ. Association between microdeletion and microduplication at $16 \mathrm{p} 11.2$ and autism. N Engl J Med 2008;358:667-75.

92 Shinawi M, Liu P, Kang S-HL, Shen J, Belmont JW, Scott DA, Probst FJ, Craigen WJ, Graham BH, Pursley A, Clark G, Lee J, Proud M, Stocco A, Rodriguez DL, Kozel BA, Sparagana S, Roeder ER, Mcgrew SG, Kurczynski TW, Allison LJ, Amato
S, Savage S, Patel A, Stankiewicz P, Beaudet AL, Cheung SW, Lupski JR. Recurrent reciprocal 16p11.2 rearrangements associated with global developmental delay, bahavioural problems, dysmorphism, epilepsy, and abnormal head size. J Med Genet 2010;47:332-41.

93 McCarthy S, Makarov V, Kirov G, Addington A, Mcclellan J, Yoon S, Perkins D, Dickel DE, Kusenda M, Krastoshevsky O, Krause V, Kumar RA, Grozeva D, Malhotra D, Walsh T, Zackai EH, Kaplan P, Ganesh J, Krantz ID, Spinner NB, Roccanova P, Bhandari A, Pavon K, Lakshmi B, lakoucheva L, Crow TJ, Christian SL, Lieberman J, Stroup S, Lehtimäki T, Puura K, Haldeman-Englert C, Pearl J, Goodell M, Willour VL, DeRosse P, Steele J, Kassem L, Wolff J, Chitkara N, McMahon FJ, Malhotra AK, Potash JB, Schulze TG, Nothen MM, Cichon S, Rietschel M, Leibenluft E, Kustanovich V, Lajonchere CM, Sutcliffe JS, Skuse D, Gill M, Gallagher L, Mendell NR, WTCC-Consortium, Craddock N, Owen MJ, O'Donovan MC, Shaikh TH, Susser E, DeLisi LE, Sullivan PF, Deutsch CK, Rapaport J, Levy DL, King M-C, Sebat J. Microduplications of 16p11.2 are associated with schizophrenia. Nat Genet 2009;41:1223-7.

94 Walters RG, Jacquemont S, Valsesia A, de Smith AJ, Martinet D, Andersson J, Falchi $M$, Chen F, Andrieux J, Lobbens S, Delobel B, Stutzmann F, El-Sayed Moustafa JS, Chèvre J, Lecoeur $C$, Vatin V, Bouquillon S, Buxton J, Boute 0 , Holder-Espinasse $M$, Cuisset J-M, Lemaitre $M$, Ambresin A, Brioshi A, Gaillard $M$, Giusti V, Fellmann F, Ferrarini A, Hadjikhani N, Campion D, Guilmatre A, Goldenberg A, Calmels N, Mandel J-L, Le Caignec C, David A, Isidor B, Cordier MP, Dupuis-Girod S, Labalme A, Salanville D, Béxi-Deixheimer $M$, Jonveaux $P$, Leheup B, Õnap K, Bochukova EG, Henning E, Keogh J, Ellis RJ, MacDermot KD, Vincent-Delorme C, Plessis G, Touraine R, Philippe A, Malan V, Mathieu-Dramard M, Chiesa J, Blaumeiser B, Kooy RF, Caiazzo R, Pigeyre M, Balkau B, Sladek R, Bergmann $S$, Mooser $V$, Waterworth $D$, Reymond A, Vollenweider $P$, Waeber $G$, Kurg A, Palta $P$, Esko T, Metspalu A, Nelis M, Elliott $P$, Hartikainen A-L, Mccarthy MI, Peltonen L, Carlsson L, Jacobson P, Sjostrom L, Huang N, Hurles ME, O'Rahilly S, Farooqi IS, Mannik K, Jarvelin M-R, Pattou F, Meyre D, Walley A, Coin L, Blakemore AIF, Froguel P, Beckmann JS. A novel highly penetrant form of obesity due to deletions on chromosome 16p11.2. Nature 2010;463: 671-5.

95 Jacquemont $S$, Reymond A, Zufferey F, Harewood L, Walters RG, Kutalik Z, Martinet $D$, Shen $Y$, Valsesia A, Beckmann ND, Thorleifsson G, Belfiore M, Bouquillon $S$, Campion D, de Leeuw N, de Vries BBA, Esko T, Fernandez BA, Fernández-Aranda F, Fernández-Real JM, Gratacòs M, Guilmatre A, Hoyer J, Jarvelin M-R, Kooy RF, Kurg A, Le Caignec C, Männik K, Platt OS, Sanlaville D, Van Haelst MM, Villatoro Gomez S, Walha F, Wu B-L, Yu Y, Aboura A, Addor M-C, Alembik Y, Antonarakis SE, Arveiler B, Barth M, Bednarek N, Béna F, Bergmann S, Beri M, Bernardini L, Blaumeiser B, Bonneau D, Bottani A, Boute O, Brunner HG, Cailley D, Callier P, Chiesa J, Chrast J, Coin L, Coutton C, Cuisset J-M, Cuvellier J-C, David A, de Freminville B, Delobel B, Delrue M-A, Demeer B, Descamps D, Didelot G, Dieterich K, Disciglio V, Doco-Fenzy M, Drunat $S$, Duban-Bedu B, Dubourg C, El-Sayed Moustafa JS, Elliott P, Faas BHW, Faivre L, Faudet A, Fellmann F, Ferrarini A, Fisher R, Flori E, Forer $L$, Gaillard D, Gerard $M$, Gieger C, Gimelli S, Gimelli G, Grabe HJ, Guichet A, Guillin O, Hartikainen A-L, Heron D, Hippolyte L, Holder M, Homuth G, Isidor B, Jaillard S, Jaros Z, Jiménez-Murcia S, Helas GJ, Jonveaux P, Kaksonen S, Keren B, Kloss-Brandstätter A, Knoers NVAM, Koolen DA, Kroisel PM, Kronenberg F, Labalme A, Landais $E$, Lapi E, Layet V, Legallic S, Leheup B, Leube B, Lewis S, Lucas J, MacDermot KD, Magnusson $P$, Marshall $C$, Mathieu-Dramard M, McCarthy Ml, Meitinger T, Mencarelli MA, Merla G, Moerman A, Mooser V, Morice-Picard F, Mucciolo M, Nauck M, Ndiaye NC, Nordgren A, Pasquier L, Petit F, Pfundt R, Plessis $G$, Rajcan-Separovic E, Ramelli GP, Rauch A, Ravazzolo R, Reis A, Renieri A, Richart C, Ried JS, Rieubland C, Roberts W, Roetzer KM, Rooryck C, Rossi M, Saemundsen E, Satre V, Schurmann C, Sigurdsson E, Stavropoulos DJ, Stefansson $H$, Tengström C, Thorsteinsdóttir U, Tinahones FJ, Touraine R, Vallée L, van Binsbergen E, Van der Aa N, Vincent-Delorme C, Visvikis-Siest S, Vollenweider $P$, Völzke H, Vulto-van Silfhout AT, Waeber G, Wallgren-Pettersson C, Witwicki RM, Zwolinksi S, Andrieux J, Estivill X, Gusella JF, Gustafsson O, Metspalu A, Scherer SW, Stefansson K, Blakemore AIF, Beckmann JS, Froguel P. Mirror extreme BMI phenotypes associated with gene dosage at the chromosome 16p11.2 locus. Nature 2011;478:97-102.

96 Pang ZP, Han W. Regulation of synaptic functions in central nervous system by endocrine hormones and the maintenance of energy homoeostasis. Biosci Rep 2012;32:423-32.

97 Golzio C, Willer J, Talkowski ME, Oh EC, Taniguchi Y, Jacquemont S, Reymond A, Sun M, Sawa A, Gusella JF, Kamiya A, Beckmann JS, Katsanis N. KCTD13 is a major driver of mirrored neuroanatomical phenotypes of the $16 p 11.2$ copy number variant. Nature 2012;485:363-7.

98 Blumenthal I, Ragavendran A, Erdin S, Klei L, Sugathan A, Guide JR, Manavalan P, Zhou JQ, Wheeler VC, Levin JZ, Ernst C, Roeder K, Devlin B, Gusella JF, Talkowski ME. Transcriptional consequences of $16 \mathrm{p} 11.2$ deletion and duplication in mouse cortex and multiplex autism families. Am J Hum Genet 2014;94:870-83.

99 Bochukova EG, Huang N, Keogh J, Henning E, Purmann C, Blaszczyk K, Saeed S, Hamilton-Shield J, Clayton-Smith J, O'Rahilly S, Hurles ME, Farooqi IS. Large, rare 
chromosomal deletions associated with severe early-onset obesity. Nature 2010;463:666-70.

100 Ren D, Zhou Y, Morris D, Li M, Li Z, Rui L. Neuronal SH2B1 is essential for controlling energy and glucose homeostasis. J Clin Invest 2007;117:397-406.

101 Morris DL, Cho KW, Rui L. Critical role of the Src homology 2 (SH2) domain of neuronal SH2B1 in the regulation of body weight and glucose homeostasis in mice. Endocrinology 2010;151:3643-51.

102 Ullmann R, Turner G, Kirchhoff M, Chen W, Tonge B, Rosenberg C, Field M, Vianna-Morgante AM, Christie L, Krepischi-Santos AC, Banna L, Brereton AV, Hill A, Bisgaard AM, Müller I, Hultschig C, Erdogan F, Wieczorek G, Ropers HH. Array CGH identifies reciprocal 16p13.1 duplications and deletions that predispose to autism and/or mental retardation. Hum Mutat 2007;28:674-82.

103 Jarick I, Volckmar A-L, Pütter C, Pechlivanis S, Nguyen TT, Dauvermann MR, Beck S, Albayrak Ö, Scherag S, Gilsbach S, Cichon S, Hoffmann P, Degenhardt F, Nöthen MM, Schreiber S, Wichmann H-E, Jöckel K-H, Heinrich J, Tiesler CMT, Faraone SV, Walitza S, Sinzig J, Freitag C, Meyer J, Herpertz-Dahlmann B, Lehmkuhl G, Renner TJ, Warnke A, Romanos M, Lesch K-P, Reif A, Schimmelmann BG, Hebebrand J, Scherag A, Hinney A. Genome-wide analysis of rare copy number variations reveals PARK2 as a candidate gene for attention-deficit/ hyperactivity disorder. Mol Psychiatry 2014;19:115-21.

104 Mefford HC, Muhle H, Ostertag P, von Spiczak S, Buysse K, Baker C, Franke A, Malafosse A, Genton P, Thomas P, Gurnett CA, Schreiber S, Bassuk AG, Guipponi M, Stephani U, Helbig I, Eichler EE. Genome-wide copy number variation in epilepsy: Novel susceptibility loci in idiopathic generalized and focal epilepsies. PLoS Genet 2010;6:e1000962.

105 Bradshaw NJ, Christie S, Soares DC, Carlyle BC, Porteous DJ, Millar JK. NDE1 and NDEL1: Multimerisation, alternate splicing and DISC1 interaction. Neurosci Lett 2009:449:228-33

106 Bakircioglu M, Carvalho OP, Khurshid M, Cox JJ, Tuysuz B, Barak T, Yilmaz S, Caglayan O, Dincer A, Nicholas AK, Quarrell O, Springell K, Karbani G, Malik S, Gannon C, Sheridan E, Crosier M, Lisgo SN, Lindsay S, Bilguvar K, Gergely F, Gunel M, Woods CG. The essential role of centrosomal NDE1 in human cerebral cortex neurogenesis. Am J Hum Genet 2011;88:523-35.

107 Alkuraya FS, Cai X, Emery C, Mochida GH, Al-Dosari MS, Felie JM, Hill RS, Barry BJ, Partlow JN, Gascon GG, Kentab A, Jan M, Shaheen R, Feng Y, Walsh CA. Human mutations in NDE1 cause extreme microcephaly with lissencephaly. Am J Hum Genet 2011:88:536-47.

108 Paciorkowski AR, Keppler-Noreuil K, Robinson L, Sullivan C, Sajan S, Christian SL, Bukshpun P, Gabriel SB, Gleeson JG, Sherr EH, Dobyns WB. Deletion 16p13.11 uncovers NDE1 mutations on the non-deleted homolog and extends the spectrum of severe microcephaly to include fetal brain disruption. Am J Med Genet $A$ 2013;161:1523-30.

109 Edelmann L, Pandita RK, Spiteri E, Funke B, Goldberg R, Palanisamy N, Chaganti RSK, Magenis E, Shprintzen RJ, Morrow BE. A common molecular basis for rearrangement disorders on chromosome 22q11. Hum Mol Genet 1999:8:1157-67.

110 Scambler PJ. The 22q11 deletion syndromes. Hum Mol Genet 2000;9:2421-6.

111 Drew LJ, Crabtree GW, Markx S, Stark KL, Chaverneff F, Xu B, Mukai J, Fenelon K, Hsu P, Gogos JA, Karayiorgou M. The 22q11.2 microdeletion: fifteen years of insights into the genetic and neural complexity of psychiatric disorders. Int I Dev Neurosci 2011;29:259-81.

112 Gothelf $D$, Presburger G, Levy D, Nahmani A, Burg M, Berant M, Blieden LC, Finkelstein Y, Frisch A, Apter A, Weizman A. Genetic, developmental, and physical factors associated with attention deficit hyperactivity disorder in patients with velocardiofacial syndrome. Am J Med Genet B Neuropsyhiatric Genet 2004;126B:116-21.

113 Philip N, Bassett A. Cognitive, behavioural and psychiatric phenotype in 22q11.2 deletion syndrome. Behav Genet 2011;41:403-12.

114 Jonas RK, Montojo CA, Bearden CE. The 22q11.2 deletion syndrome as a window into complex neuropsychiatric disorders over the lifespan. Biol Psychiatry 2014;75:351-60.

115 Karayiorgou M, Morris MA, Morrow B, Shprintzen RJ, Goldberg R, Borrow J, Gos A, Nestadt G, Wolyniec PS, Lasseter VK, Eisen H, Childs B, Kazazian HH, Kucherlapati R, Antonarakis SE, Pulver AE, Housman DE. Schizophrenia susceptibility associated with interstitial deletions of chromosome 22q11. Proc Natl Acad Sci USA 1995;92:7612-6.

116 Ensenauer RE, Adeyinka A, Flynn HC, Michels VV, Lindor NM, Dawson DB, Thorland EC, Lorentz CP, Goldstein JL, MCDonald MT, Smith WE, Simon-Fayard E, Alexander AA, Kulharya AS, Ketterling RP, Clark RD, Jalal SM. Microduplication 22q11.2, an emerging syndrome: clinical, cytogenetic, and molecular analysis of thirteen patients. Am J Hum Genet 2003;73:1027-40.

117 Courtens W, Schramme I, Laridon A. Microduplication 22q11.2: A benign polymorphism or a syndrome with a very large clinical variability and reduced penetrance?-Report of two families. Am J Med Genet A 2008;146A:758-63.

118 Portnoï MF. Microduplication 22q11.2: a new chromosomal syndrome. Eur J Med Genet 2009;52:88-93.

119 Rees E, Kirov G, Sanders A, Walters JTR, Chambert KD, Shi J, Szatkiewicz J O'Dushlaine C, Richards A, Green EK, Jones I, Davies G, Legge SE, Moran JL, Pato
C, Pato M, Genovese G, Levinson D, Duan J, Moy W, Göring HHH, Morris D, Cormican P, Kendler KS, O'Neill F, Riley B, Gill M, Corvin A, WTCC-Consortium, Craddock N, Sklar P, Hultman C, Sullivan PF, Gejman PV, McCarroll S, O'Donovan MC, Owen MJ. Evidence that duplications of 22q11.2 protect against schizophrenia. Mol Psychiatry 2014;19:37-40.

120 Meechan DW, Maynard TM, Tucker ES, Fernandez A, Karpinski BA, Rothblat LA, Lamantia A-S. Modeling a model: Mouse genetics, 22q11.2 Deletion Syndrome, and disorders of cortical circuit development. Prog Neurobiol 2015;130:1-28.

121 Yagi H, Furutani Y, Hamada H, Sasaki T, Asakawa S, Minoshima S, Ichida F, Joo K, Kimura M, Imamura S, Kamatani N, Momma K, Takao A, Nakazawa M, Shimizu N, Matsuoka R. Role of TBX1 in human del22q11.2 syndrome. Lancet 2003:362:1366-73.

122 Yavich L, Forsberg MM, Karayiorgou M, Gogos JA, Männistö PT. Site-specific role of catechol-0-methyltransferase in dopamine overflow within prefrontal cortex and dorsal striatum. J Neurosci 2007;27:10196-209.

123 Yamaguchi Y, Lee Y-A, Goto Y. Dopamine in socioecological and evolutionary perspectives: implications for psychiatric disorders. Front Neurosci 2015;9:1-11.

124 Glatt SJ, Faraone SV, Tsuang MT. Association between a functional catechol 0-Methyltransferase gene polymorphism and schizophrenia: meta-analysis of case-control and family-based studies. Am J Psychiatry 2003;160:469-76.

125 Jacquet $H$, Raux $G$, Thibaut $F$, Hecketsweiler B, Houy E, Demilly C, Haouzir S, Allio G, Fouldrin G, Drouin V, Bou J, Petit M, Campion D, Frébourg T. PRODH mutations and hyperprolinemia in a subset of schizophrenic patients. Hum Mol Genet 2002;11:2243-9.

126 Paterlini M, Zakharenko SS, Lai W-S, Qin J, Zhang H, Mukai J, Westphal KGC, Olivier B, Sulzer D, Pavlidis P, Siegelbaum SA, Karayiorgou M, Gogos JA. Transcriptional and behavioral interaction between 22q11.2 orthologs modulates schizophrenia-related phenotypes in mice. Nat Neurosci 2005;8:1586-94.

127 Vorstman JAS, Turetsky BI, Sijmens-Morcus MEJ, De Sain MG, Dorland B, Sprong M, Rappaport EF, Beemer FA, Emanuel BS, Kahn RS, Van Engeland H, Kemner C. Proline affects brain function in 22q11DS children with the low activity COMT 158 allele. Neuropsychopharmacology 2009;34:739-46.

128 Hiroi N, Takahashi T, Hishimoto A, Izumi T, Boku S, Hiramoto T. Copy number variation at 22q11.2: from rare variants to common mechanisms of developmental neuropsychiatric disorders. Mol Psychiatry 2013;18:1153-65.

129 Vassos E, Collier DA, Holden S, Patch C, Rujescu D, St Clair D, Lewis CM. Penetrance for copy number variants associated with schizophrenia. Hum Mol Genet 2010;19:3477-81.

130 Kirov G, Rees E, Walters JTR, Escott-Price V, Georgieva L, Richards AL, Chambert $K D$, Davies $G$, Legge SE, Moran JL, McCarroll SA, O'Donovan MC, Owen MJ. The penetrance of copy number variations for schizophrenia and developmental delay. Biol Psychiatry 2014;75:378-85.

131 Nomura J, Takumi T. Animal models of psychiatric disorders that reflect human copy number variation. Neural Plast 2012;2012:1-9.

132 Provenzano G, Zunino G, Genovesi S, Sgadó P, Bozzi Y. Mutant mouse models of autism spectrum disorders. Dis Markers 2012;33:225-39.

133 Lieschke GJ, Currie PD. Animal models of human disease: zebrafish swim into view. Nat Rev Genet 2007:8:353-67.

134 Bessa C, Maciel P, Rodrigues AJ. Using C. Elegans to decipher the cellular and molecular mechanisms underlying neurodevelopmental disorders. Mol Neurobiol 2013;48:465-89.

135 Zhang R, Zhang L, Xie X. iPSCs and small molecules: a reciprocal effort towards better approaches for drug discovery. Acta Pharmacol Sin 2013;34:765-76.

136 Bozdagi O, Sakurai T, Dorr N, Pilorge M, Takahashi N, Buxbaum JD. Haploinsufficiency of Cyfip1 produces fragile X-like phenotypes in mice. PLOS ONE 2012;7:e42422.

137 Fejgin K, Nielsen J, Birknow MR, Bastlund JF, Nielsen V, Lauridsen JB, Stefansson $H$, Steinberg S, Sorensen HBD, Mortensen TE, Larsen PH, Klewe IV, Rasmussen SV, Stefansson K, Werge TM, Kallunki P, Christensen KV, Didriksen M. A mouse model that recapitulates cardinal features of the $15 q 13.3$ microdeletion syndrome including schizophrenia- and epilepsy-related alterations. Biol Psychiatry 2014;76:128-37.

138 Horev G, Ellegood J, Lerch JP, Son Y-EE, Muthuswamy L, Vogel H, Krieger A, Buja A, Henkelman RM, Wigler M, Mills AA. Dosage-dependent phenotypes in models of 16p11.2 lesions found in autism. Proc Natl Acad Sci USA 2011;108:17076-81.

139 Kiehl TR, Chow EWC, Mikulis DJ, George SR, Bassett AS. Neuropathologic features in adults with 22q11.2 deletion syndrome. Cereb Cortex 2009;19:153-64.

140 Meechan DW, Tucker ES, Maynard TM, Lamantia A-S. Diminished dosage of $22 q 11$ genes disrupts neurogenesis and cortical development in a mouse model of 22q11 deletion/DiGeorge syndrome. Proc Natl Acad Sci USA 2009;106:16434-45.

141 Meechan DW, Tucker ES, Maynard TM, LaMantia A-S. Cxcr4 regulation of interneuron migration is disrupted in 22q11.2 deletion syndrome. Proc Natl Acad Sci USA 2012;109:18601-6.

142 Drew LJ, Stark KL, Fénelon K, Karayiorgou M, MacDermott AB, Gogos JA. Evidence for altered hippocampal function in a mouse model of the human 22q11.2 microdeletion. Mol Cell Neurosci 2011;47:293-305.

143 Fénelon K, Xu B, Lai CS, Mukai J, Markx S, Stark KL, Hsu P-K, Gan W-B, Fischbach GD, MacDermott AB, Karayiorgou M, Gogos JA. The pattern of cortical 
dysfunction in a mouse model of a schizophrenia-related microdeletion. J Neurosci 2013;33:14825-39.

144 Xu B, Hsu P-K, Stark KL, Karayiorgou M, Gogos JA. Derepression of a neuronal inhibitor due to miRNA dysregulation in a schizophrenia-related microdeletion. Cell 2013;152:262-75

145 Ellegood J, Markx S, Lerch JP, Steadman PE, Genç C, Provenzano F, Kushner S, Henkelman R, Karayiorgou M, Gogos J. Neuroanatomical phenotypes in a mouse model of the 22q11.2 microdeletion. Mol Psychiatry 2014;19:99-107.

146 Dolmetsch R, Geschwind DH. The human brain in a dish: the promise of iPSC-derived neurons. Cell 2011;145:831-4.

147 Takahashi K, Tanabe K, Ohnuki M, Narita M, Ichisaka T, Tomoda K, Yamanaka S. Induction of Pluripotent Stem Cells from Adult Human Fibroblasts by Defined Factors. Cell 2007;131:861-72.

148 Kim D-S, Ross PJ, Zaslavsky K, Ellis J. Optimizing neuronal differentiation from induced pluripotent stem cells to model ASD. Front Cell Neurosci 2014;8:1-16.

149 Brennand K, Savas JN, Kim Y, Tran N, Simone A, Hashimoto-Torii K, Beaumont KG, Kim HJ, Topol A, Ladran I, Abdelrahim M, Matikainen-Ankney B, Chao S-H, Mrksich M, Rakic P, Fang G, Zhang B, Yates JRIII, Gage FH. Phenotypic differences in hiPSC NPCs derived from patients with schizophrenia. Mol Psychiatry 2015;20:361-8

150 Brennand KJ, Simone A, Jou J, Gelboin-Burkhart C, Tran N, Sangar S, Li Y, Mu Y, Chen G, Yu D, McCarthy S, Sebat J, Gage FH. Modelling schizophrenia using human induced pluripotent stem cells. Nature 2011;473:221-5.

151 Brennand KJ, Gage FH. Modeling psychiatric disorders through reprogramming. Dis Model Mech 2012;5:26-32.

152 Miller DT, Adam MP, Aradhya S, Biesecker LG, Brothman AR, Carter NP, Church DM, Crolla JA, Eichler EE, Epstein CJ, Faucett WA, Feuk L, Friedman JM, Hamosh A, Jackson L, Kaminsky EB, Kok K, Krantz ID, Kuhn RM, Lee C, Ostell JM, Rosenberg C, Scherer SW, Spinner NB, Stavropoulos DJ, Tepperberg JH, Thorland EC, Vermeesch JR, Waggoner DJ, Watson MS, Martin CL, Ledbetter DH. Consensus statement: chromosomal microarray is a first-tier clinical diagnostic test for individuals with developmental disabilities or congenital anomalies. Am J Hum Genet 2010;86:749-64.

153 Moreno-De-Luca D, Sanders SJ, Willsey AJ, Mulle JG, Lowe JK, Geschwind DH, State MW, Martin CL, Ledbetter DH. Using large clinical data sets to infer pathogenicity for rare copy number variants in autism cohorts. Mol Psychiatry 2013;18:1090-5.

154 Veltman JA, Brunner HG. Understanding variable expressivity in microdeletion syndromes. Nat Genet 2010;42:192-3.
155 Girirajan S, Rosenfeld JA, Cooper GM, Antonacci F, Siswara P, Itsara A, Vives L, Walsh T, Mccarthy SE, Baker C, Mefford HC, Kidd JM, Browning SR, Browning BL, Dickel DE, Levy DL, Ballif BC, Platky K, Farber DM, Gowans GC, Wetherbee JJ, Asamoah A, Weaver DD, Mark PR, Dickerson J, Garg BP, Ellingwood SA, Smith R, Banks VC, Smith W, McDonald MT, Hoo JJ, French BN, Hudson C, Johnson JP, Ozmore JR, Moeschler JB, Surti U, Escobar LF, El-Khechen D, Gorski J, Kussmann J, Salbert B, Lacassie Y, Biser A, McDonald-McGinn DM, Zackai EH, Deardorff MA, Shaikh TH, Haan E, Friend KL, Fichera M, Romano C, Gécz J, DeLisi LE, Sebat J, King M-C, Shaffer LG, Eichler EE. A recurrent 16p12.1 microdeletion suggests a two-hit model for severe developmental delay. Nat Genet 2010;42:203-9.

156 Moss EM, Batshaw ML, Solot CB, Gerdes M, McDonald-McGinn DM, Driscoll DA, Emanuel BS, Zackai EH, Wang PP. Psychoeducational profile of the 22q11.2 microdeletion: a complex pattern. J Pediatr 1999;134:193-8.

157 Zufferey F, Sherr EH, Beckmann ND, Hanson E, Maillard AM, Hippolyte L, Mace A, Ferrari C, Kutalik Z, Andrieux J, Aylward E, Barker M, Bernier R, Bouquillon S, Conus P, Delobel B, Faucett WA, Goin-Kochel RP, Grant E, Harewood L, Hunter JV, Lebon S, Ledbetter DH, Martin CL, Mannik K, Martinet D, Mukherjee P, Ramocki $M B$, Spence SJ, Steinman KJ, Tjernagel J, Spiro JE, Reymond A, Beckmann JS, Chung WK, Jacquemont S. A $600 \mathrm{~kb}$ deletion syndrome at $16 \mathrm{p} 11.2$ leads to energy imbalance and neuropsychiatric disorders. J Med Genet 2012;49:660-8.

158 Moreno-De-Luca A, Myers SM, Challman TD, Moreno-De-Luca D, Evans DW, Ledbetter DH. Developmental brain dysfunction: Revival and expansion of old concepts based on new genetic evidence. Lancet Neurol 2013;12:406-14.

159 Stefansson $H$, Meyer-Lindenberg A, Steinberg S, Magnusdottir B, Morgen K, Arnarsdottir S, Bjornsdottir G, Walters GB, Jonsdottir GA, Doyle OM, Tost $H_{\text {, }}$ Grimm O, Kristjansdottir S, Snorrason H, Davidsdottir SR, Gudmundsson LJ, Jonsson GF, Stefansdottir B, Helgadottir I, Haraldsson M, Jonsdottir B, Thygesen JH, Schwarz AJ, Didriksen M, Stensbøl TB, Brammer M, Kapur S, Halldorsson JG, Hreidarsson S, Saemundsen E, Sigurdsson E, Stefansson K. CNVs conferring risk of autism or schizophrenia affect cognition in controls. Nature 2014;505:361-6.

160 Van den Veyver IB, Patel A, Shaw CA, Pursley AN, Kang S-HL, Simovich MJ, Ward PA, Darilek S, Johnson A, Neill SE, Bi W, White LD, Eng CM, Lupski JR, Cheung SW, Beaudet AL. Clinical use of array comparative genomic hybridization (aCGH) for prenatal diagnosis in 300 cases. Prenat Diagn 2009;29:29-39.

161 Firth HV, Richards SM, Bevan AP, Clayton S, Corpas M, Rajan D, Van Vooren S, Moreau Y, Pettett RM, Carter NP. DECIPHER: Database of Chromosomal Imbalance and Phenotype in Humans Using Ensembl Resources. Am J Hum Genet 2009;84:524-33. 